\title{
THE METIS OF MANITOBA: \\ REFORMULATION OF AN \\ ETHNIC IDENTITY
}

\section{A Thesis \\ Presented to \\ The Faculty of Craduate Studies and Research The University of Manitoba}

In Partial fulfillment

of the Requirements for the Degree

Master of Arts

Department of Anthropology

by

Joe Sawchuk

February 1973

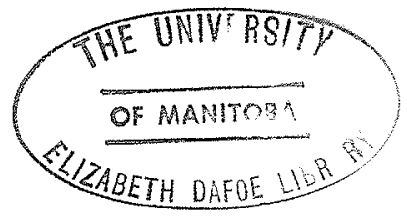




\section{ACKNOWLEDGEMENTS}

I would like to express my gratitude to the members of my thesis committee; to Dr. Ray Wiest for his encouragement and advice throughout the writing of this thesis, and to Dr. Louise E. Sweet and Dr. W.W. Koolage, Jr. for their constructive criticisms and helpful suggestions.

I would also like to thank all my friends at the mmF who made my work there so enjoyable; Dr. S.W. Corrigan, who gave me my first real taste of anthropology; and to Pat, for her criticisms, proofreading, and encouragement, which helped to make it all possible. 
ACKNOWLEDGEMENTS $\ldots \ldots \ldots \ldots \ldots \ldots \ldots \ldots \ldots \ldots \ldots \ldots \ldots \ldots \ldots \ldots \ldots \ldots$

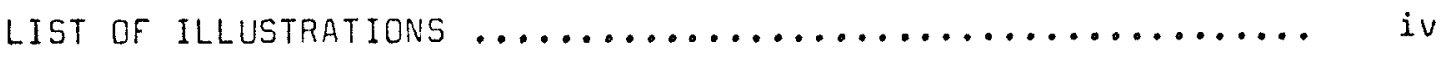

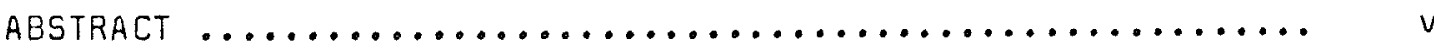

Chapter

1. INTRODUCTION $\ldots \ldots \ldots \ldots \ldots \ldots \ldots \ldots \ldots \ldots \ldots \ldots \ldots \ldots$

Objectives

Relationship to Existing Literature and Research

Methodology

Definition of Basic Terms

Framework for Analysis

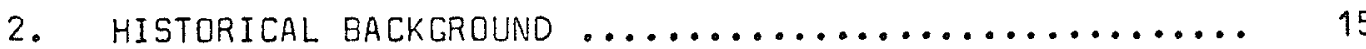

Territory
Origins
Characteristics
Metis Nationalism
A History of the Metis as an Ethnic Group

3. CONTEMPORARY FORCES OF ETHNIC AWARENESS AMONG THE METIS 34

4. THE MANitoBa METIS FEdERATION ................. 45

Historical Sketch

Organization of the MmF

Operation of the MmF

Contacts With Other Native Crganizations

Representativeness of the Organization

Representativeness of the Leaders

5. VOLUNTARY ORGANIZATIONS AND ETHNICITY ............ 74

Group Cohesiveness

The MMF and Metis Identification

Conclusions

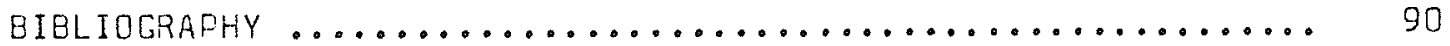


LIST OF ILLUSTRATIONS

Page

Original MmF Regional Boundaries .................. 53

Present mif Regional Boundaries ..................... 54

The Adninistrative Structure of the MMF .............. 57 
THE METIS OF MANITOSA:

REFORMULATION OF AN ETHNIC IDENTITY

The Metis of Manitoba present the opportunity of investigating the wide ranging effects which voluntary organizations can make on the cohesiveness and boundary maintenance of ethnic groups.

In western Canada, the term Metis is generally used to describe a person of mixed Indian and white ancestry, who does not have legal Indian status. However, many people who would fit that description would not use the term to describe themselves, and those who do accept it represent a broad spectrum of individuals, from those living in the small French-speaking communities of southern Manitoba, to those living on, or on the fringes of, Indian reserves.

The term metis has not had a precise meaning since the 19th century, when it referred specifically to the French-speaking halfbreed: of the Red River Settlement and adjacent areas, who also referred to themselves as the bois brule (charcoal faces) and the New Nation. But the ethnic group known as metis today represents a drastic reformulation of the criteria that defined the New Nation of the 19th century. I contend that the concept of metis has acquired a new content in terms of criteria for membership in the group, social organization, attitudes toward the surrounding majority of the population, and attitudes toward themselves. The manitoba metis Federation (MMF) is seen as one of the main vehicles of this change, contributing a feeling of ethnicity to a 
remarkably diverse group of people, many of whom would have actively denied the term Metis a few years ago.

The propositions made in this thesis are based on observations I made while working for the MMF as a researcher on a remote housing evaluation program, and on fieldwork done in several metis communities in northern and southern Manitoba under the supervision of $5 . W$. Corrigan. The resurgent feelings of ethnicity among the Metis are defined in term of the cohesiveness of the group. Cohesiveness refers to the forces which keep a person in the group and prevent him from leaving. The operation of the MMF has contributed heavily to the cohesiveness of the Metis in two ways: (1) it has demonstrated that there is a common threat stemming from an outside source, and (2) that there exists the possibility that cooperative behaviour may reduce or eliminate the threat. The threat from the outside source is represented by the fact that the metis are being held down in a position of low mobility and poverty by the dominant society. The effectiveness of cooperative behaviour is represented by the improved housing, the community development programs and the new employment opportunities the federation has achieved for its members and other Metis.

Structurally and functionally, this new political process is in marked contrast to that which once served to identify the metis of the 19th century. In order to meet the changing conditions of contemporary society, the Metis of Manitoba have had to accept a drastic modification of the boundaries that once defined their group; it is a reformulation with historical continuity of what was once a distinct ethnic group in western Canada. 


\section{CHAPTER 1}

INTRODUCTION

\section{Objectives}

Voluntary organizations ${ }^{1}$ can often have a profound effect upon ethnic group organization and the strengthening of ethnic identity. A good example of this phenomenon is afforded by an analysis of the resurgence of ethnicity amang the Metis of Manitoba and an examination of the role that one voluntary organization, the Manitoba Metis Federation (MMF) is playing in this resurgence.

The importance of ethnic identity as a human motivation is well known. Today as in the past there is ample evidence of its power in contemporary politics, as all over the world groups of people attempt to preserve their cultural identity from the dominant society which surrounds them. Some examples that readily come to mind include the tendency towards separatism in Quebec, the Black Power movement in America, the long history of feuding in Northern Ireland, the many separatist groups that abound in India, and the continuing emphasis on ethnicity by European immigrant groups and by Native peoples in Canada and the United States.

\footnotetext{
1 "institutionalized groups in which membership is attained by joining" (Little 1965:1).
} 
These movements are not solely concerned with the preservation of identity, however. They also represent policies adopted by minority groups in response to their clearly underprivileged position with regard to the society around them. Thus most contemporary ethnic organization is political in nature, concerned with dealing with the strong institutional and organizational arrangements of modern society which keep these people in a position of low mobility and poverty. But preservation of identity (particularly by strengthening it at the ethnic group level) represents one way in which groups might be able to emerge from poverty.

This is the strategy which is at present being pursued by the metis of western Canada. Their main vehicle for social change is the MMF, which was chartered to provide a united voice for the Metis, to help them solve their poor economic position, and to solve the attendant problems of poverty such as poor housing and poor health. In pursuing these ends, the MmF has succeeded in drawing many people together who a few years ago would have denied the name metis. In bringing about this drastic change in membership, the MmF has been instrumental in the reformulation of what was once a distinct ethnic group of western Canada.

This is an interesting development, because the term Metis has not had a precise meaning since the latter half of the 19 th century when it was used to describe the french-speaking half-breeds of the Red River Settlement and adjacent areas. In later years, the term Motis has been used loosely to describe any person of mixed Indian and white 
ancestry in Canada, ranging from individuals living on, or on the fringes of, Indian reserves, to those living in the small frenchspeaking Metis communities of southern manitoba, as well as those who are partly or wholly integrated into white society.

To add to the confusion, many of these people have refused to use the term metis in describing themselves. For many years the term was almost unknown in Manitoba, and the only reason it showed up with such regularity in the literature was because the alternative -- "halfbreed" -- was felt to be an even more disparaging term. However, this was in fact the common terminology for years. In his report on the people of Indian ancestry in Manitoba, Lagasse stated that less than 10 percent of the people interviewed who had mixed Indian and white ancestry referred to themselves as metis (1958:50, Vol. I). Some of the people interviewed stressed the Indian portion of their background, while others referred to themselves as "half-breeds" or stressed their European background. Some people still feel that "metis" properly refers only to those persons who are of French and Indian descent. But the concept of Metis has changed drastically in the last few years, acquiring a new content in terms of criteria for membership in the group, social arganization, attitudes towards the surrounding majority of the population, and attitudes towards themselves. It is my contention that the Manitoba Metis Federation is one of the major factors influencing this recent reformulation of ethnicity. 
Relationship to Existing Literature and Research

Although there has been a large amount of literature devoted to the Mietis, very little of it has been from the viewpoint of social analysis. Most of it is historical in nature, dealing with the role played by the metis in the early development of Canada (e.g. A.S. Morton 1939a; Stanley 1936a; Giraud 1945; W.L. Morton 1957). Of the historical treatments, Giraud's (1945) is by far the most comprehensive and well known, dealing as it does with the history of the metis people from their first appearance to their near disappearance following the rebellion of 1885.

of the literature that could be described as having mainly anthropological or sociological interest, the one most relevant to this study is Lagasse's three volume report on the people of Indian descent in Manitoba (1959). This socio-economic study deals in depth with the Metis, describing their distribution, historical background, and identity as of 1958 .

Slobodin's work on the Metis of the Northwest Territories (1966) deals at length with Metis identification, but the main focus is on a descriptive treatment of the composition of the family, the kinship system, occupation, and education. Also, his emphasis on identification is slightly different from that used in this study, since he uses the term Metis to cover any self-identification that admits to a person's mixed racial background, whether that person describes himself as Metis or not (1966:149-150). I, on the other harid, arn interested in thase people who identify with the term metis, and with what that term means 
to them.

The Canadian Association of Social Workers produced a short work on the Metis of Manitoba (CASW 1954). This study was undertaken because of the special difficulties social workers were experiencing in dealing with Metis individuals and families. This interesting booklet gives a thumbnail sketch of who the Metis are, what has been done to help them, and makes recommendations to various governments on policies regarding the Metis.

In 1963, Card, Hirabayashi and French conducted a study of the Metis of "Improvement District 124" in northern Alberta. They made an intensive study of the incidence and ecology of tuberculosis among the Metis, covering the social, economic and cultural parameters of this population in order to determine how these factors affect the high incidence of tuberculosis found in this group. Thus the study has sections dealing with such subjects as ethnic relations, constitution of households, motivations, and so on, in addition to a straightforward treatment of the subject of tuberculosis.

Buckley, Kew and Hawley have produced a work on the Indians and Metis of Northern Saskatchewan (1963). This work, done for the Center for Community Studies, University of Saskatchewan, deals mainly with the prospects for economic development of the province. Buckley also did an earlier work on the trapping and fishing economy of the metis of Northern Saskatchewan.

Valentine produce! a short work for the Department of Natural Resources on the Metis of Northern Saskatchewen (1955). The purpose 
of this report was to acquaint the "interested administrator" with some features of northern Metis life. The material was collected during the summers of 1952, 1953 and 1954, and deals with how the people live in various northern communities, a historical sketch, and the problems of administration. An earlier work by this author deals with the problems of Metis fur trappers (1954).

\section{Methodology}

I first became interested in the problems of Metis identification and in the operation of the MMF in the summer of 1970 when I visited several Metis communities in both the northern and southern regions of Manit va. This was done as part of a study under the supervision of S.W. Corrigan concerned with determining some of the social and cultural boundaries of these people, in areas ranging from social organization to housing, education and economic opportunities and aspirations.

I first became aware of the work of the MMF through contacts with the local representatives at St. Laurent, a small Metis community in the Interlake region of Manitoba. I had a further opportunity to meet the MMF representatives of a MMF local in January of 1970 , when I spent ten days in Churchill, Manitoba as a part of a team of 12 interviewers administering a questionnaire directed toward discovering the attitudes of townspeople towards medical services provided there. I concentrated my interviews in the metis and Cree community of River flats, working with an interpreter who was an active member of the Mm. local. I also attended several Mimif meetings in such small northern communities as 
Grand Rapids, The Pas, and Big Eddy.

These experiences gave me some idea as to how the MmF was being run on the local level, and sharpened my interest in how the federation operated provincially. However, I was unable to satisfy my interest until the spring of 1971 when I had the opportutnity of working for the MMF as a researcher on their Remote Housing Evaluation Project. This project, which came into being as a result of consultation between the MMF and the Manitoba Housing and Renewal Corporation, was concerned with an analysis of the effectiveness of a remote housing program initially implemented in 1968 to alleviate the extremely poor housing conditions in Metis communities.

During the course of my work for the federation, I had an opportunity to visit several more Metis communities, including Duck Eay, Camperville, Amaranth, Eddystone and Bacon Ridge, all in the Dauphin Region of the MmiF.

The information in this thesis has thus come from various field trips to widely scattered communities in Manitoba and from general observations while working for the federation. It should be stressed here that the conclusions drawn in this thesis hold mainly for the metis in Manitoba, although I will be drawing parallels from works on Metis in other provinces.

Most of the information for this study was gathered in informal discussions with people I met on field trips, members of the staff of the MMF, and with visitors to the offices of the federation. Several of the more formal interviews were tape reçorded. I asked many 
individuals about their feelings on being Metis, attempting to get them to answer questions about:

1 How they regarded themselves (did they call themselves Metis?);

2 How they regarded other Metis (specifically community leaders and the founders of the MMF);

3 Their attitudes towards the legal definitions of Indian status, and how they looked upon Indians and the Manitobo Indian Brotherhood.

From staff members of the Federation I asked additional

questions aimed at:

1 The constitution of the MMF

2 History of the MMF

3 The aims and objectives of the organization

4 The administrative structure

5 The representativeness of the organization (that is, which communities were covered, the number of members, who joined the organization and who didn't)

6 The various programs of the MMF

\section{Definition of Basic Terms}

1. Metis The typical definition assumes that any person who has a mixed Indian and European ancestry, and who does not have Indian status, is a Metis. Obviously, all human populations are "mixed" in heredity -a point Slabodin has covered thoroughly $(1966: 1-9)$. In this study, unless it is stated otherwise, the term Metis will refer to those persons specifically referring to themselves as Metis. However, there are many categories of people who use the term metis to describe them- 
selves, so that additional refinement of the definition is required. In an attempt to avoid confusion, I shall borrow terms from Slobodin (1966) to distinguish between these different populations where necessary.

The term "Red River Metis" will be used to describe those Matis who "derive geneologically, and usually in tradition, from the historic population which had its centre in la nation metisse of the western plains" (slobodin 1966:14). I shall use "northern Metis" as a residual term, used to describe those who are not closely identified with the "Red River" Metis. This term is not particularly valid for Manitoba, since it could cover many individuals who do not come from areas that could be accurately described as northern Manitoba. It should generally be taken to refer to those individuals who identify more closely with the Indian side of their ancestry than do the Red River Metis. I am reluctant to use these terms, since they are not used by the people themselves, and therefore I will only use them when it is necessary to distinguish between the two populations.

I stress identification with the word "retis" because there are individuals of mixed parentage who regard themselves as Indians, regardless of their legal status. These people often live on reserves (when they are allowed to) and are for all intents and purposes indistinguishable from their neighbours who possess Indian status. Alternatively, others have cut themselves off from their Indian background and joined the dominant white society. There is little justification for referring to either of these types of individuals as metis. 
2. Ethnic Croup An ethnic group is regarded as a population which (1)

is "largely biologically self-perpetuating"; (2) "shares fundamental cultural values"; (3) "makes up a field of communication and interaction"; and (4) has a membership which is identified by itself and others as a "category distinguishable from categories of the same order" (Barth 1969:10-11). Barth himself tends to put most of the weight on the latter criterion (1969:13-14).

There has been a debate in the literature over the relative merits of stressing this approach which concentrates on the actors' identification of themselves, as opposed to the use of criteria such as language type and territorial contiguity, for example Naroll 1954; 1967a; 1967b; 1970; Moerman 1965; 1967a; 1967b; Bessac 1967; Barth 1969. Naroll originally proposed the term "cultunit" (1964) to denote the general concept of the culture-bearing unit, based on the criteria of language, political organization and territorial contiguity. Moerman, who became interested in the problem of ethnic unit classification when he had trouble in answering the question "Whom did you study in the field?" (1965:1215), relied more heavily on the actors' identification of themselves, and was critical of Naroll's concept because the categories derived would often bear little resemblance to the actors' conception of themselves.

Barth is opposed to Naroll's type of analysis on two counts: (1) it entails a prejudicial view of which traits are actual determinants of the unit, and (2) it arques a congruence between the ethnic group and a culture which may not be borne out by the facts (1969: 
11-13). Furthermore, since ethnic groups usually imply contact between groups, one would expect to find a reduction of cultural differences. But the reduction of cultural differences "does not correlate in any simple way with a reduction in the organizational relevance of ethnic identitjes, or a breakdown in boundary-maintaining processes (Barth 1969:32-39). This concept has some important implications which will become apparent in the section on identifying features of the Metis. A great deal of the controversy regarding the identification of ethnic groups is due to the fact that some of the participants do not take into account the objectives of their opponents. Naroll's main emphasis was on creating a taxonomy for cross-cultural comparison (1964:288) and as far as he is concerned, the native concept is not particularly useful for this. In fact, it is "almost irrelevant" to him whether the units so derived have any correspondence to the native categories (1967:512)。

I mention this controversy because I am more interested in the way the Metis regard themselves than with the peculiar cultural traits by which they might be recognized; indeed, later on I will demonstrate that these particular traits are few and far between, and despite the importance accorded them by the actors themselves, seem almost "trivial" (Moerman 1967:156) when considered in terms of Naroll's scheme. Easing an approach on Naroll's criteria would ignore the basic process of ethnic unit existence, the contrastive process that defines a person as being a member of a group by virtue of his not being a member of another group. An example of the difficulty of identifying groups by 
ethnic traits can be seen in the problems encountered by the various Interamerican Indigenist Congresses in coming out with a satisfactory distinction between Indian and mestizo. After many abortive attempts to come up with a definition that would be of use to the majority of the American countries participating in the congresses, which was to be based on "linguistic, cultural, and social criteria" the majority of countries have simply taken the Indian language as the basis for identification in their censuses, a solution which has not yet answered the question of who or "when" is an Indian (Flores 1967:15-20).

Barth arques that the persistence of boundaries is accomplished by a limited set of cultural features, so it follows that most of the culture is not constrained by the boundary. In other words, culture bearing units and ethnic groups are not the same thing. In order to depict any given population, one does not have to give a full description of their "culture", but concentrate on the social aspects that differentiate them from other groups.

McFeat also suggests that these differentiating characteristics are in terms of social processes as opposed to cultural markers; his so-called "binary-system" locks the ethnic group into the more inclusive system from which it cannot be extricated -- the system of "us" and "them" (1970:29).

Identification by natives thus concentrates the emphasis on the contrastive aspects of the ethnic group: who is in the group and who isn't. Thus the membership in any group "... is dependent upon a category of the excluded, a sense of otherness" (Moerman 1965:1215). 
The metis and the Indians that live next to them might be regarded as constituting a single cultural unit, yet they are not regarded as such by themselves or their neighbours. The Metis are separated from the Indians by their legal status and by "white characteristics", and are separated from the whites by their Indian characteristics. It is primarily a negative sort of identification; they are Metis because they are not somebody else.

A word of caution is necessary here. Self-identification, while it might help answer the question of who are the Metis, does not shed much light on the problem of why the Metis exist. It does not explain the forces behind the identification. And while certain cultural features can be selected that can be shown to be significant to the natives, these are not scientific explanations of the processes of ethnic group maintenance. Moerman has commented on the tendency of anthropologists to elevate folk-beliefs (such as ethnic labelling) to "analytical works" (1967:154), remaining content to stop with the reporting of certain dichotomies of groups rather than seeing these as a challenge to explain.

But the emphasis on social processes as markers for ethnic groups does take into account the very real probability that there does not exist anywhere a tatally unique and labelled set of people. It also stresses that there is not necessarily any correspondence between a named set and a distinctive and homogeneous culture. 


\section{Framework for Analysis}

It is my contention that the athnic group we know today as metis actually represents a radically different group of people from the 19 th century Metis who formed the political organization known as the "New Nation". The Metis of the 20th century represent an ethnic group which, in order to survive as a viable unit, has had to shift its boundaries considerably to include many people who originally would not have been considered to be members of the group. In order to demonstrate this hypothesi:; the thesis will have the following format:

Chapter 2 will deal with a history of the Red River Metis, the rebellions of 1870 and 1885 , and the subsequent status of the Metis.

Chapter 3 will describe the Metis of Manitoba today, concentrating on the forces of ethnic awareness that operate on this diverse population.

Chapter 4 will concentrate on the history, structure and function of the MmF, describing its aims and method of operation.

Chapter 5 will deal with the analysis of the cohesiveness of the Metis as an ethnic entity, and the role that the MmF is playing in this cohesiveness. 
CHAPTEA 2

HISTORICAL BACKCROUND

\section{Territary}

The Metis of western Canada originated in the lands west of the Great Lakes, mainly the Red River Valley and the interior plains of North America, but to a lesser extent on the western shores of Hudson Bay as well. These territories had been first entered by fur traders and explorers following the inland water routes in search of new sources of furs. There had been considerable interest in the area since 1670, when the Hudson's Bay Company had been granted control of all lands whose waters flowed into Hudson Bay. This territory, known as "Rupert's Land" covered a vast area, including the Red River drainage basin. However, the Hudson's Bay Company did not actually lay claim to the Red River Valley until 1805.

It was the french who were the real pioneers in this area; Verandre built Fort Rouge at the forks of the Assiniboine and Red River in 1736, giving the French a claim to the territory which they held until 1763 when by the Treaty of Paris all Canada passed to the control of the British (Dunleavy 1941:86). While the HBC had been content to set up fur-trading posts on the west coast of Hudson Eay, letting the Indians bring their furs to them, the french began to enter the country in force, using the Lake Superior route to cut off the flow of furs to the English. This began the rivalry between 
the Montreal and London fur interests which was to last until 1821.

The Hudson's Bay Company's greatest rival in the area was the North west Company, formed in 1784. Unlike the HBC, which was an incorporated body with exclusive trading privileges, this group of Scottish and french traders formed a network of voluntary partnerships, basing their right to trade in this area upon the claims of prior exploration (Pritchett 1942:87). The Red River Valley was the center of the battle ground of these two great companies, and it is in this setting that the metis come into being.

\section{Drigins}

With the appearance of French, Scottish and English traders in the West, a new ethnic group, the metis or half-breed began to emerge. The white men began to marry among the native population of the area, the Cree, Saulteaux and Assiniboine. The Cree were the original inhabitants of the Red River Valley, and their women were regarded as especially attractive wives by the newcomers (Howard 1952:39). By 1775 a prairie Metis population was definitely in existence, and it is possible that this group had originated as early as the 40's or 50's of the 18th century (Pritchett 1942:14). At around the same time, there were enough mixed bloods in the vicinity of Hudson Bay for them to be noted as a separate group as well (Lagasse 1959:51). These two groups did not emerge at the same rate. The French Canadians at Red River, long used to the mixed marriages of New France, looked upon the intermingling of the races on the plains as a matter of corrse. In fact, the voyageurs 
who made the journey to Red River from New France were often of mixed blood themselves. In contrast to this situation, the Hudson's Bay Company officially disapproved of alliances with Indian women and undertook to punish breaches of morality (Stanley 1947:430). However, despite this official disapproval, there occured a growth of mixed blood population on the Bay. Part of this group migrated south when Hudson's Bay men moved to the banks of the Red River after the establishment of Lord Selkirk's colony at the forks. After 1835 the Hudson's Bay Company changed its policies regarding Indian-white marriages, and more employees became married and settled down with their families (Lagasse 1959:51).

\section{Characteristics of the Metis of the Red River Valley}

1. Ethnic Veriations The members of the half-breed population which had sprung up on the western plains were knoun by many names -- because of their dark complexions the french half-breeds often referred to themselves as "bois-brules", that is, charcoal faces (Pritchett 1942;15). Their mixed blood was referred to in the term "Metis", a common term as well. Later they were to refer to themselves as the "New Nation". But the half-breeds were not all of French origin; many of their names were Scottish or English. Generally, the french group was referred to as "Metis" and the English group as "half-breeds" although it has been reported that this latter group resented the name, preferring the term "native" (Reade 1885:11-12).

The parents of the metis were usually "free men"; employees of the North west Company who had taken their discharge and remained in the 
Northwest, held there by their Indian wives and families (Macleod and Morton 1968:14). The French from the East were known simply as "Canadians", as Ross (1856) refers to them. According to Ross, the Canadians and the Metis settled together, although there were some differences in their modes of life. The half-breeds could be distinguished by their mode of dress:

We had not proceeded far before we met a stout, well-made, good looking man, dressed in a common blue capote, red belt and corduroy trousers; he spoke French, and was a Canadian. That, said I, pointing to his dress, is the universal costume of both Canadians and half-breeds, the belt being a simple badge of distinction; the former wearing it generally over, and the latter as generally under the capote (Ross 1856:190).

Despite their common Indian background, neither the Englishspeaking or French-speaking half-breeds on the western plains wholly identified with each other at that time. They differed from each other in too many ways, such as religion, preferred occupation, and areas of settlement.

The French part of the population is, as a class, migratory. They go to the prairies to hunt buffalo, or man the Hudson's Bay Company's boat and cart brigades. The part of the settlement in which they live may be described as both banks of that portion of the Red River lying to the south of its junction with the Assiniboine and the southern bank of the latter river. They are all of the Roman Catholic religion. The English half-breed population and the Scotch ... are devoted mainly to agricultural pursuits, and inhabit that part of the settlement situated on the Red River between Upper and Lower Fort Carry, being a space of twenty miles, including the most valuble portion of the colony, and the northern bank of the Assiniboine. with the exception of the Scotch, who are presbyterians, this portion of the population is Episcopalian (Hargrave 1871:174). 
2. Dccupation By far the most important industry in Red River was the buffalo hunt. The area had never been a particularly rich fur country, but in order to exploit the rich fur regions further west it was necessary to furnish food for the trading posts and canoe brigades. Pemmican, made from the meat and fat of the plains buffalo, furnished cheap and plentiful provisions. Thus it was provisions rather than furs that made the Red River country of such paramount importance to the fur trade, and which caused the two rival companies to maintain posts in the area.

At first the buffalo were hunted in the summer by those running the posts, and by freemen and their half-breed sons. As buffalo hunting became more important, the Metis began to specialize in it. They began to organize elaborate expeditions out into the plains to run the buffalo on horseback.

This was not the only livelihood open to the Metis; Ross referred to a second class who lived by fishing. There were other occupations open as well. The "tripmen" were usually Metis but sometimes English half-breeds who worked on the boat brigades used in the transport of trade goods and furs. There was also an overland freighting system by cart to St. Paul, Minnesota (Stanley 1936a:14).

As the half breeds of Red River grew more numerous, many of the influential and important positions were filled by them as well, although this was mostly true of the English-speaking portion. ... it is an interesting fact that the half castes or mixed race, not only far outnumber all the other races in the colony put together, but engross nearly all the more important and intellectual 
offices -- furnishing from their number the sherrif, medical officer, the post master, all the teachers but one, a fair proportion of the magistrates and one of the electors and proprietors of the only newspaper in the Hudson's Bay territories (A.K. Istister, as quoted by W.L. Morton 1957:91).

3. Class Structure There was a distinct class structure among the half-breeds, marked by occupation. At the top was the bourgeoisie represented by the farmers in the Red River settlement. Then followed the traders, carters, boatmen and guides employed by the fur companies. At the bottom were the buffalo hunters. Generally the farmers and traders were English half-breeds, while the french half-breeds' principle activity was the buffalo hunt (Stanley 1942:432).

But although the buffalo hunters were accorded the lowest status in relation to the colony as a whole, among the metis themselves ranking was based upon an entirely different set of criteria. Ross subdivides the French half-breeds into three groups. At the top were the buffalo hunters -- "the more wealthy or venturesome class", a second and "inferior" class lived by fishing, followed by a third class who "follow no regular calling or profession"(1856:84-86).

Thus there was a basic dichotomy between the English and French half-breeds, as evidenced by their class differences. This difference was further emphasized by the practice of many English and Scottish traders of sending their half-breed sons to Montreal or abroad for their education.

4. Relations Between the English and French Half-greeds it is easy to 
over-emphasize the differences between the English and French halfbreeds. After all they both had common bonds; they both claimed territorial rights through their Indian ancestry, and they both spoke their Indian tongue in addition to English or French. During the Red River Rebellion and the Insurrection of 1885 , there was considerable support for the French Metis among the English half-breeds. In reading contemporary descriptions of the Metis we come across such individuals as Jean Baptiste Wilkie, an English half-breed brought up by the French (Ross 1856:193). It is also known that Cuthbert Grant, a Scotch halfbreed and "Captain of the Metis" had two brothers-in-law who were French Metis (Macleod and Morton 1963:18). This indicates that there probably was some intermarriage between the two groups.

The French speaking half-breeds always made up the majority of the population of Red River, but the English speaking half-breeds made up a sizable proportion of the mixed population, in 1870 numbering 4,083 as compared to 5,757 French speaking Metis (Lagasse 1959:52).

\section{Metis Nationalism}

An inevitable question presents itself when we study the halfbreeds of Red River. Why did the Metis emerge as a separate racial and national unit? What was it that made the west such an ideal setting for the appearance of a new ethnic group? There had been interbreeding between whites and Indians as early as the first visit of white men to this continent, and in New France, while certain governors attempted to discourage free unions with Indian women, marriage had never been 
totally eliminated by either the administration or the clergy. Why then did these half-breeds born in Eastern Canada not acquire a separate identity? And why did those born on the prairies become able to think of themselves as a separate unit, and refer to themselves as the "New Nation"?

Most authorities (for example Morton 1939b; Ciraud 1949; Stanley 1936a) attribute the rise of the sentiments of nationalism among the half-breeds and Metis of Red River to the conflict over fur rights, and more specifically to the North West Company's deliberate policy of antagonism towards Lord Selkirk's colony.

Basically, their argument is as follows: the Hudson's Bay Company allowed the establishment of Lord Selkirk's colony because it gave them two advantages. First, it would provide the company with cheap labor and provisions, helping them to reduce costs in the struggle with the North West Company, and secondly, it would act as a proclamation of the compary's right to the territory, and a warning to the Nor'Westers to keep out.

The Nor'Westers, to whom this was all too clear, set about to destroy the Selkirk settlement, using the natives as their tools of destruction. They began to instill into the minds of the french halfbreeds in their employ the idea that the Metis, by virtue of their Indian blood, were the real "Lords of the Soil". According to morton (1939b:139) the first trace of this tactic was reported in the winter of 1812-13. By the winter of 1815-16 "the principle that the land belonged to the Indians and metis has taken definite form".

These plats of the North West Company are what most historians 
feel formed the basis of half-breed nationalism and ultimately the Red River Rebellion itself. But this is not entirely convincing. While these occurences undoubtably contributed to the national unity of the Metis, it is a gross exaggeration to make such a statement as "At the door of the North West Company must be laid the responsibility for raising the racial consciousness of the metis" (Stanley 1936:11), implying as it does that the Metis were "created" as an ethnic group by the intrigues of a few fur traders in the Northwest.

These intrigues of the North Uest Company would have met with little success had there not been a solid basis for the concept of national unity. One important factor fostering this unity was the close association the Metis had with the fur companies (Macleod and Morton 1963:14). The white parents of the Metis had often been traders associated with the posts, or freemen who after their discharge remained in the Northwest. They often worked as hunters or casual laborers for the company, and so were dependent on it, unlike their Indian relatives.

However, the most important factor contributing to Metis nationalism was the buffalo hunt. This more than anything else contributed to the corporate sense of the Metis, and assumed more and more importance as they began to specialize in the hunt as a means of livlahood. There is no need to give a detailed description of the hunt here; one can turn to Alexander Ross' detailed and vivid description of the 1840 hunt in his work The Red River Settlement $(1856: 241-274)$. It should be sufficient here to point out that the successful deployment of a body of men that could number 1,630 or mare (the 1840 hunt) 
necessitated a great deal of discipline and planning on the march as well as during the hunt itself. On the 1840 hunt, order was maintained by ten captains, each of whom had under his command ten soldiers. Ten guides were likewise appointed, and when this army of hunters was on the move, it was the guides who were the chiefs of the expedition, the captains and soldiers being subject to them. Once the march was halted and camp about to be set up, the captains and soldiers took over command. A comprehensive set of rules was set up to help maintain order; for example, no buffalo were to be run on Sunday, no party was allowed to fork off, lag behind or go forward without permission, no party was allowed to run buffalo before the general order, and so on (Ross 1856:249).

"Racial" feelings also had a contributing effect on the growth of the Metis as a separate unit, giving rise to a fixed population of half-breeds. The half-breed usually loaked upon himself as above the true-born Indian, and while half-breed men occasionally married Indians, the half-breed women almost invariably married within their own group, or more rarely, among the whites (Stanley 1947:430). Alexander Ross mentions an incident in which a white objected to, and successfully prevented, the marriage of his daughter to an English half-breed (1856: $238-239)$

Thus the Nor'westers' appeal to Metis nationalism already had a solid basis (social organization, marriage patterns, racial feelings) upon which to draw. 


\section{A History of the Metis as an Ethnic Croup}

1. Prior to the Red River Rebellion of 1870 As mentioned earlier, the Metis were observed on the western plains as early as 1775 . Lord Selkirk made the first attempt to found a colony at Red River in 1812. By 1816, the ill feelings the North West Company had sowed among the Metis caused the situation to reach a climax with the "massacre at Seven Daks". However, this did not mean the end of the settlement, and the struggle to form a permanent colony continued until Lord Selkirk's death in 1820. When the North West Company and the Hudson's Bay Company united in 1821 under the name Hudson's Bay Company, both parties were convinced that colonization was incompatible with the fur trade, and for the next forty years, this was the predominant interest in Rupert's Land. Ironically, this did not mean the end of the Red River settlement. The colony continued to grow, not by immigration from Canada or Europe, but by settlement of the half-breed and white employees of the fur trade. The colony was not only filled by those retiring from the service, but by the many clerks and voyageurs that were thrown out of work when the two companies united. The colony changed from a white settlement to a half-breed settlement, and the population doubled within a few years. It was reported that although the population had increased by 1,232 during the years 1849 to 1856 , the number of European or Canadian families had decreased by 102 (5tanley 1939a:13).

During this period of time, the principle occupation was the buffalo hunt, followed by freighting and farming. The colony was administered by the Hudson's Bay Company since the death of Lord 
Selkirk (in 1836 they were officially given back control from Lord Selkirk's heirs) and they governed until 1869.

A local governor and council was appointed to conduct the affairs at Red River. The clergy, both Roman Catholic and Protestant were represented, as were the half-breeds, both English and French. The work of the council covered the whole life of the colony, from the issue of marriage licenses to the encouragement of local industries (Stanley 1936a:16).

Thus for a period of forty years, nearly two generations, a predominantly half-breed society existed in the Red River Settlement, cut off from the outside world by the Hudson's Bay Company's opposition to colonization. But the fur trade could not stem the tide of white immigration into the west forever, and it was only a matter of time before the competitive civilization of the 19 th century would overwhelm the economically and politically simple society of Red River.

An increasing number of settlers began to arrive at Red River from the East. Once there, they began advocating annexation of Rupert's Land to Canada. By 1850 it was evident that the days of company rule in British North America were numbered.

The half-breeds viewed this growing immigration with alarm. As they had demonstrated years before at Seven Daks, they considered this country to be theirs. They knew that they could not survive the large influx of white settlers which would inevitably follow the transfer of the country to the Dominion of Canada. The advent of settlers in Red River would mean the end of the fur trade, the buffalo 
hunt and the freighting business. Louis Riel stated the case succinctly when he told the Council in 1869 that the half-breeds "were uneducated, and only half civilized, and felt, if a large immigration were to take place, they would probably be crowded out of a country they claimed as their own" (Stanley 1936a:49).

In 1869-70, in the face of arrangements made for the final transfer of Rupert's Land to the Dominion of Canada, the Metis, supported to some extent by the English half-breeds, established a Provisional Covernment under the leadership of Riel. The ultimate result of this was that the colony was transferred to Canada not as a territory but as a province. Among other things, the Manitoba Act promised 1,400,000acres of land to be distributed among the halfbreeds (Stanley 1936a:244) and the metis hoped that this would help them to hold their own against the increasing flow of Canadians. Eut although the half-breed rebellion was politically successful, the metis were doomed to economic absorption. No act of parliament could protect them indefinitely, and in a few years, despite the concessions they had gained, the half-breeds were swept away by a flood of newcomers.

2. The western metis Prior to the Insurrection of 1885 The period immediately following the frod River Rebellion was an era of persecution for the metis. There were open conflicts between the natives and the Canadian forces, and the metis found their lands being forcibly taken by newcomers from Ontario (Stanley 1936a:165-166). Their usual occupations were no longer profitable or possible. Many Metis who were 
entitled to "scrip" (land grents) did not get any, while others became discouraged, selling their title for a pittance and heading west.

At that time, the country beyond Manitoba was known as the Northwest Territories. It had become Dominion property at the same time that Manitoba had become a province. Following the disturbance at Red River, a huge half-breed trek to the Northwest began (Giraud 1954:1). This movement had started even before the rebellion, due to the gradual withdrawal of the buffalo further and further west, which began to make the long journey after them unprofitable. Thus, rather than return to their homes in the Red River Settlement, the Metis who followed the buffalo trails into the interior built provisional quarters for the winter.

These "winter camps" were usually built near a wood to provide housing material and fuel, close to a stream or river, and not too far from the vicinity of the buffalo herds (5tanley 1936b:403). These camps, which were used year after year, began to achieve permanent status with the construction of 109 houses and the establishment of missions.

Dnce again, free of the effects of colonization, the Metis were able to regroup and rebuild their society. One of the most important centers of this new society was st. Laurent, originally a winter camp built in the neighbourhood of Duck Lake, in what is now Saskatchewan. On December 10,1873 , the metis of $5 t$. Laurent met to form a provisional government, using the laws of the buffalo hunt as its basis (Stanley 1936b:404). A council and president was elected, and a code 
of regulations, covering nearly the whole life of the community was adopted. Taxes were collected, a commission to settle boundary disputes and ownership of land was formed, and formal shape to the traditional rules of the buffalo hunt was set down for the first time. But despite this high level of political development, st. Laurent was no more safe from extinction than the Red River Settlement was. The settlement of the Northwest had not been confined to the Metis. As early as 1866 a white settlement was established at Prince Albert and by 1878 the editor of the Saskatchewan Herald could boast that "the buffalo hunter is rapidly giving way to the farmer, and the Indian trader to the merchant" (Stanley 1936a183).

Inevitably, the metis of the Northwest found themselves facing the same situation they had faced at Red River a few years before. Using the Manitoba Act as a precedent, the Metis from all over the Northwest began to petition the government for land grants as a part of their aboriginal rights. However, years of inaction on the part of the government, as well as the unfamiliar system of land survey that was forced upon the Metis caused a great deal of discontent. Finally in May 1884, driven to desperation by the government's refusal to acknowledge thair needs, the Metis of St. Laurent sent for Louis Riel, in exile in the United States, and ultimately precipitated the "halfbreed rebellion" of 1885. But the Metis gained little by this action, and within a few years it could be said that the Metis no longer functioned as a tightly organized and discrete ethnic unit. 
3. From 1885 to the Present There is little to relate after the rebellion of 1885. This uprising did not benefit the metis any more than did the previous one at Red River. Giraud (1955:1-15) describes the disintegration of the Metis as an ethnic group following the insurrection. They had been unable to stem the economic transformations over the territories they had regarded as their own, and had to stand by and watch it being taken over by newcomers. They were fearful over reprisals stemming from the insurrection, and many fled to American territory. Those that stayed behind had little to look forward to. A commission was established in March of 1885 to grant lands to the Metis, using the same criteria as had been used in Manitoba. But most of the Metis who received land became victims of land speculators, and the rest chose "money scrip" instead, in hope of an immediate profit. Thus the majority of the Metis became dispossessed of any land, and once their small capital was dissipated, became destitute, since they were now deprived of the resources of buffalo hunting and freighting.

With the exception of such occasional jobs as building railway lines or coach routes, gathering buffalo bones for fertilizer, or doing odd jobs for white farmers, there was little opportunity for employment. Thus the metis nation became scattered throughout the West, with its people generally living in extreme poverty, waiting for whatever chance occupation might come along.

Lagasse shows evidence that the metis began to deny their identity, giving their Europeon background as their national identity. 
He quotes Dominion census figures which point to 2,000 fewer Metis or half-breeds in Manitoba in 1886 than in 1870. The 1941 census, the last to include a separate listing for the Metis listed only 8,692; there had been 9,830 in 1870. (1958:54).

The disintegration of the Metis as an ethnic group was hastened by the federal government's long-standing reluctance to recognize the Metis as an ethnic entity possessing legitimate aboriginal rights. This policy was made quite clear when the first treaties (numbers 1 to 7 ) were signed with the Indians of the Northwest Territories and Manitoba. At that time the government refused to recognize any aboriginal rights possessed by the Metis unless they wholly identified with the Indians (Morris 1880:41). It is true that the Manitoba Act of 1870 was so worded as to give the impression that the land grants awarded the metis were a formal acknowledgement of these rights. Section 31 of that act states:

And whereas, it is expedient, towards extinguishment of the Indian Title to the lands in the province, to appropriate a portion of such ungranted lands, to the extent of one million four hundred thousand acres thereof, for the benefit of the families of the halfbreed residents... (Statutes of Canada, 33 Vict. Cap. 3 Sec. 31; 25-26, emphasis mine).

But later it was found convenient to deny that these lands were given as an acknowledgement of aboriginal rights, and it was in fact maintained that this was simply a policy to "put down turbulent feelings" in that part of the country. According to sir John A. Macdonald:

That phrase (the extinguishment of the Indian title) 
was an incorrect one, because the half-breeds did not allow themselves to be Indians. If they are Indians, they go with the tribe; if they are half-breeds they are whites, and they stand in exactly the same relation to the Hudson Bay Company and Canada as if they were altogather white (Official Report of the Debates of the House of Commons, July $6,1885: 3113)$.

This last quote is a succinct statement of the policies of the federal government regarding the recognition of the metis. Either a person is an Indian, and has a treaty number, or else he is a white man. Thus it is hardly surprising that the Metis Nation of Saskatchewan, the organization equivalent to the MMF in Manitoba, referred to the Metis as "non-people".

The Metis nation in Saskatchewan, as indeed in all Canada and generally in North America, find ourselves in the unsavory position of being non-people. It is the law and custom of this country to list people ancestrally according to the nationality of the male parent.... There is a sector on society which is legally referred to as "Indian" and which can prove its lineage by a demoralizing device known as a "treaty number"... We, their brothers and sisters, who through some accident of history do not possess an identifying number are left unable to produce identity... (Metis Nation of Saskatchewan 1970:3).

There had been sporadic efforts, either on the part of the clergy, or by the metis themselves to rectify the injustices done to them. The clergy had suggested as early as 1890 the establishment of a reserve for the metis, and were finally able to convince the government to establish the 5t. Paul de Metis Reserve in 1896 (Ciraud 1956:11-15). However, it failed due to insufficient government assisstance. The Metis at Lesser Slave Lake unsuccessfully undertook to obtain government assistance in 1911 against the frauds that had 
resulted from the trafficking in land scrips, and in the years following the First World War same Metis again attempted to seek redress from the frauds that had victimized them (Giraud 1955:10-11). But generally it was a long time before the Metis began to act again in any corporate sense, and it was not until the middle 1960's that special organizations began to appear in Canada aimed at the economic and social strengthening of the metis. It is this final development that this thesis is intended to document. 
CHAPTER 3

CONTEMPORARY FORCES OF ETHNIC AWARENESS AMONG THE METIS

The term Metis has quite different connotations today than it had in the early 1800 's when it implied an identification with a distinct and specific group of people -- the french-speaking halfbreeds of the Red River Settlement. Today it is more commonly used to refer to anyone with mixed Indian and white ancestry, and includes a great many people with quite different backgrounds. One Metis informant astutely pointed out that the Metis today could most accurately be pictured as a continuous spectrum of individuals, from those whose life-styles are completely white, to those completely Indian. So the term as it is used today can refer equally well to the "Red River" Metis, who can demonstrate an unbroken history with the "New Nation" of the 1800's, to persons of mixed blood of relatively recent origin, even first generation. It can even be sometimes be used to refer to persans who have totally assimilated into white society. But even though the term has come to refer to a quite different group of people than it did originally, it still has many strong connotations of ethnic awareness associated with it, and many people who share the term metis feel that they have something in common. It is with this feeling of ethnicity that this chapter is concerned. 
The distinction between ethnic groups and culture-bearing units as discussed in Chapter 1 has particular relevance with regard to the Metis. The metis exhibit no distinctive language, dress, arts, crafts, or easily recognizable physical type. But despite this, and despite the total destruction of the political state that once defined them, they represent to themselves and to a good portion of the people around them, a distinct ethnic entity. How then, does one recognize a metis? In any situation of contact between ethnic groups, one would expect to find certain signals -- "symbols of ethnic awareness" (Bessac 1967:60) that would demarcate ethnic boundaries. The cultural content of these traits does not have to be high; when Moerman compiled a list of the overt traits that separated the Lue from their Yuan neighbours (1967:156-157) he was struck by their apparent "triviality", despite the importance accorded them by the natives themselves.

Barth, in commenting on the signals demarcating ethnic boundaries, postulated that the only importan ones were those the actors themselves considered significant (1969:14). Some of the actual differences would be used by the actors, but some would be ignored, even radical or obvious ones. Barth further subdivided these contents into two orders: (1) overt signs and signals (such as dress, language, life-style) and (2) basic value orientations (1969:14).

In attempting to isolate the demarcating traits of metis ethnic existence, it is almost easier to define what is not a signal for Metis than isolating one that is. The traditional signals that Barth 
mentions (dress, language, house-form or life-style) do not offer much to work with here. Most of the traits the Metis exhibit are also shared with other cultures. For example, while most metis have a second language, there is no one language that successfully demarcates the speaker as being Metis. He may speak English, French, Cree, or Saulteaux, but he doesn't speak "Metis".

Physical appearance offers little indication either. There is no obvious Metis phenotype -- many individuals exhibit no "Indian" features whatsoever, and are indistinguishable from whites, while others look more like Indians than many people possessing Indian status do.

Dress offers no help either. There are a few ethnic groups in Manitoba who advertise their ethnicity in manner of dress, but the Metis are not one of these. It is unlikely that a Metis, usually interested in taking part in the dominant society would be likely to adopt something that would isolate him even more from that society. This attitude can be seen in an anecdote related to me by an individual concerning the time he was attending a social animation conference on behalf of the MMF:

I remember I was at a meeting one time (a kind of a social animation thing) and somebody came along and said "Well, I don't see anything about you that indicates that you are a metis -- look at you, you've got a suit on, you got a shirt and tie..." so I got madder'n hell, I said "What the hell you expect me to wear? A coonskin cap?"

There is a large range of activity such as beadwork, leather working, and so on that can be regarded as Indian arts and crafts. A certain proportion of metis take part in these activities, and some 
Metis have even told me that it is the Metis who have kept this tradition alive rather than the Indians. But despite this claim, these activities are shared with Indians and so do not serve to identify the metis. One exception which I have seen is the weaving of a "Metis sash" which supposedly is a replica of the belts once worn by the voyageurs. But this tradition can only be truly said to belong to the "Red River" Metis. These activities also seem to have little relevance to those metis who are interested in taking a more active part in the dominant society, as this Metis makes clear:

In the case of the Metis, this almost leaves them out, because there are the Metis who have reached the stage of sophistication, if that's the right terminology, where arts and crafts as such are not that meaningful. People are involved in -- they're farmers, they could be professional people, teachers, something else. They're not going to sit down and start making snowshoes....

One of the difficulties in pinpointing such cultural markers is dependent on the fact that we are dealing with a relatively recent reformulation of a once distinct past and tradition. Also, one can see a tendency for Metis to suppress cultural differences because of the discrimination faced by them. For a long time, there was little effort made on their part to keep their traditions alive.

This does not mean that there are no examples of ethnic awareness, however. The metis will often call attention to the differences between their way of 1 ife and that of their neighbours, both Indian and white. One way in which the Metis justify their separateness from the dominant culture is to critisize the value system of the whites, at the same time praising their own more "altruistic" way of life. 
One Metis expressed this idea in these words:

Where I come from, I'm a rancher, you are judaed by the number of cows you own. Just on the number of goddamn cows... We live in a society in which the value system is based on material possessions, on your rank, if you want to call it that, or on the amount of money you got -- your bank account, your education, so on and so forth. But our value system is based on human beings...human beings are more important than cows, or high academic standing, or the degrees that go with it, or bank accounts, or you name it.

If you want me to be a little more specific when I say the value system, I would say that the native people are -- they live in a more or less communal society, where they believe that they should share, and they do share. For the most part, you go to a Metis home, they will never tell you "We would like to put you up for the night but there is no room." They'd sleep on the floor, and say "Oh yeah, we can put you up, you can sleep right here." I'm not saying about all white men, but many white people will come up and say "Well, we don't have a spare bedroom, so sorry, but we can't put you up." We live very different...

Notice that this is a distinction between white values and that of the Metis and not between that of the Indian and the Metis. It could be stated that the Indian shares the same value system with the Metis. Yet this does not imply that the metis regard themselves as one with the Indian. They resent bitterly the way they are always lumped together with the Indians by the general public. They are quick to point out their own moral superiority over Indians since they never had a "Department of iretis Affairs" to take care of them, but were forced to make their own way in the world.

Many Metis use their underprivileged position in society as a symbol of their uniqueness, distinguishing themselves not only from the white sector, but from the Indian sectio as well, since they feel 
that they have received a much worse deal from society than the Indians have.

One Metis is fond of pointing out these differences to visitors. Taking them to a reserve near his home, he shows them the relatively new and well-built houses the Indians are occupying. The reserve has no fence or boundary to mark it off, but when driving out of the reserve he points out the dilapidated shacks along the road and says "We are now leaving the Reserve and entering the metis community. That is how you can tell where the reserve leaves off and the Metis community begins!" Yet another Metis expressed a similar orientation:

The basic thing with the metis people is poverty. That is the predominant factor of that subculture -- that and the lack of education.

A similar concept was proposed as one of the distinctive characteristics of Indians in the Americas when an Indian was defined as an individual with a maximum number of needs and quantitative deficiencies together with the maximum number of qualitative needs and deficiencies (Flores 1967:18).

Poverty is not a factor which affects all metis, although it serves as a rallying point for a great many of them, particularly those who are members of the MMF. Some officials regret the emphasis on poverty that the MMF has stressed since its inception, because they feel that this has kept some groups of metis, such as professional people, business men, and successful farmers out of the organization. Hawever, it is unlikely that many of these individuals would consider joining the organization no matter what the federation stressed as its main 
aim. There are no assets the organization could provide these people. A great deal of attention is often devoted to the revival of historical traditions and culture traits to justify and glorify an ethnic identity (Barth 1969:35). The Metis have a viable historical tradition to draw upon and do so despite the fact that many of the metis who draw attention to their "historical past" ere often northern Metis whose mixed ancestry goes only one or two generations back. This can be illustrated with an interesting poster which was seen in many MMF offices as well as Indian and Metis Friendship Centres in the summer of 1971. This poster featured a portrait of Louis Riel, with bold black letters proclaiming "Nous Sommes Nouvelle Nation!" and "We are the New Nation!". This poster was not produced, as might have been expected, by a cultural or social organization such as the Union Nationale Metisse. Rather it was printed for "The New Nation", a newspaper (which has now ceased publication) aimed at the metis population of franitoba. The publisher and editor of this paper is a northern Metis, and strictly speaking has no connection with the Red River Metis who in the 1800's were proclaiming themselves to be the "New Nation". This example dramatizes the new attempts many Metis are making towards creating a viable identity for themselves, even to the extent of drawing upon the cultural symbols of a group that a few years ago was considered to be practically extinct, and which has in reality often very little connection with their background. More than anything else, it is their marainal status which serves to set the Metis apart. To the dominant white society, there is little difference between an Indian and a metis; both share the same stigma- 
tized status. Yet in many cases, especially in those involving vested interests, the Metis face rejection from the Indians as well.

The general attitude towards the Matis by the white populace is betrayed by the casual way in which they are always mentioned in conjunction with the Indians in newspapers and magazine articles, usually at inappropriate times. If the Indians at Norway House are presenting a petition to a government official, the press is almost sure to begin the article "The Indians and Metis of Norway House...." To a great many people, the Metis are simply regarded as part of Canada's "native problem" and little recognition of the differences between the statuses of Indian and Metis is accorded them.

The Metis understandably resent this attitude, and feel that it is simply yet another example of their low status. In a press release a few years ago, Angus Spence, president of the MmF was moved to speak on this subject:

The Metis are always mentioned in the same breath as the Indians but the fact remains that we are completely left out of the picture in this case...

Indians can be considered as one half of the Canadian netive peoples with the Metis considered the other half but they do not and cannot work together on every kind of project... (Winnipeg Free Press, November 6, 1970).

An additional irritant to the Metis is their uncertain legal status. The federal government has no basis for according them any special recognition, and neither has the provincial government, although the latter has dealt with them in many cases. In the same press release as above, Mr. Spence went on to sếy: 
We are nothing but a political football. We are not registered Indians so whenever we have any correspondence with the federal government, they tell us to contact the provincial government who in turn tells us we are just another ethnic group.

But no matter whether a person is considered an Indian or a Metis, he shares with the rest of the native population the stigma of inferiority that is accorded them by the rest of society. Yet if he seeks to shed his Metis identity to pursue a career in the dominant society he faces the disapproval and censure of the Metis who have made no attempt to leave their group. This syndrome is strikingly similar to that facing the Lapps with relation to the dominant Scandinavian countries, where in order to pursue successful careers in the dominant society, individuals with Lappish cultural identity must go through a process of adopting roles defined by the Scandinavian or Western European culture and abandoning roles defined by the Lappish tradition. But this is a process which involves a high personal cost:

The specific system of sanctions can be seen as a cost-mechanism which leads an individual with Lappish identity to renounce his roles as a Lapp so as to avoid the strong sanctions from Scandinavians. Lappishness has a stigma of inferiority which is sanctioned by ridicule, insults and avoidance... A Lappish individual also involves himself in similar cost from a Lappish system of sanctions by thus indicating that he is seeking to change identity. The totality of sanctions thus have a bimodal effect (Eidheim 1968:207).

Many metis find themselves caught in a similar situation of conflicting sanctions. To be Indian or Metis in Canada involves the same stigma of inferiority as that faced by the Lapps in Scandinavia. 
In order to pursue a career in business, the civil service, or politics, many a metis has found it convenient to forget his Indian background. Yet these persons are often condemined by other metis for attempting to hide their ethnic origins.

Despite the stigmatized status they share with Indians (scarcely being recognized as a distinct ethnic entity by the dominant saciety) the metis face rejection from the Indian population as well. This is especially true in situations where conflict over vested interests is involved. Indians have the right to close the reserve to any nonstatus person, and one often finds cases of Metis who may have grown up on a reserve being forced to move off. Some older Metis speak of a time when there were no schools available for Metis communities. The government was at that time setting up special schools for the Indians, but Metis families could only send their children to these schools "if the families got along with the local chief" (Winnipeg Tribune, July 27, 1971)。

A good example of the effect of ethnic dichotomization where the control of resources is concerned occurred in April of 1972, when several Indian bands got approval from the provincial motor transport board to operate their own taxi services on or near the reserves. The Indians then banned the Metis operators of several existing taxi services from entering the reserves with their taxis. The mmF lodged a complaint about this, but there was little they could do about it since the Indians have the right to close their reserves to all non-Indian traffic or pedestrians.

As can be seen by the traits discussed here, the main thing that 
sets the Metis apart is their marginal status. The Metis themselves reinforce their identity by calling attention to the differences in their way of life, emphasizing their underprivileged position in society, and by reviving the historical traditions of their past glory. But the important differentiating characteristics are not based so much on "cultural objects" (such as distinct heritage, separate language, or manner of dress) as they are on political, legal, and social markers. Many metis actually feel that they have little in the way of a unifying culture, as is implied in the following anecdote of an MMF official:

I'm always lost when you speak of metis culture.
I've asked this question before and have never
really had it answered to my satisfaction. [An
MIB official] once asked me "What is Metis culture?"
"Cood question," I asked him, "What the hell is
culture?" "Well," he said, "Language is culture."
He asked me what language I spoke and I told him
Saulteaux. "Well," he said, "That's my language..."

There is one distinctive marker of the Metis which I have deliberately avoided discussing to this point -- the mm. The importance of the MMF as a factor in Metis identification warrants a chapter in itself, and will be dealt with in Chapter 5. But in order to fully appreciate the importance of the MMF, a detailed look at the structure and function of the organization is first in order, and this is the subject of the next chapter. 


\title{
CHAPTER 4
}

\author{
THE MANITOBA METIS FEDERATION
}

The Manitaba Metis Federation is a non-profit voluntary organization whose avowed purpose is to achieve recognition of the Metis people and their special problems, to educate them in the social action necessary for them to make use of various government services available, and to better their economic position. It can thus be described as a "social influence" or "instrumental" organization (Rose 1965: $391-2)$, that is, one which has as its main concern the bringing about of a change in society that will be beneficial to the group the organization represents.

The instrumental organization exists in contrast to what Rose Iefers to as the "expressive" organizations, those which are formed to express the specialized areas which are of interest only to the members themselves. These organizations include recreational and sport associations, social and hobby clubs, and professional societies.

The MMF, particularly as manifested in its local organizations, has a strong expressive element in its make-up. The locals often sponser recreational events such as picnics, dances and bingo games, and while these local events are of great importance to the members of the communities, the main objectives of the federation lie in the "instrumental" category, and it is with these objectives that I shall 
be dealing exclusively.

Although the mis is a voluntary organization, its administrative network has progressed to the point where it must now make use of several full-time paid employees such as secretaries and administrators, as well as retaining the services of specialists such as lawyers and consultants whenever these are needed. However, the highest governing body of the association (the Board of Directors) still consists of unpaid members and executives. For example, the presidency and vicepresidencies are all unpaid positions.

The costs of running the federation are for the most part met by government grants. In additional to straight operational grants which allow the federation to stay in operation, special grants are often awarded in the support of some project (such as the Remote Housing Evaluation Project) which, because of the contractual obligations that go with the receipt of the grant, has the result of the organization acting as a semi-official arm of the government.

This position is somewhat ironic since the executives of the federation do not see their organization as a problem-solving unit. Their philosophy is "social action" -- that is, getting people to help themselves, to learn how to solve their own problems. This attitude is reflected in the way the federation is organized, where a great deal of local autonomy is encouraged. However, in some instances, the organization is finding itself in the role of problem solving. 


\section{Historical Sketch}

Prior to the incorporation of the MMF in 1967, the primary vehicle for social action for people of either Indian or Metis descent was the annual Indian and Metis Conference that was sponsered by the Community Welfare Planning Council of Winnipeg. However, this was not particularly satisfactory to the Metis, a common complaint being that the distribution of delegates was always set up to favor the Indian population. Thus, it would not be uncommon for the conference to dwell primarily on topics of interest to treaty Indians, such as treaty rights and band councils. Topics of interest to Metis were often tabled or ignored.

The MMF had its beginnings in the 1950's, when the Indian and Metis Conferences began to apply pressure to the different levels of government for housing programs. There was a fundamental difference in the problems faced by the Indians and those faced by the Metis. The federal Department of Indian Affairs had introduced a housing program for the reserves but the metis, as unregistered Indians, were ineligible to take advantage of this program. Several housing associations were formed to apply pressure on the provincial government for metis housing programs. These housing associations amalgamated to form the Manitoba retis Housing Association, and initiated housing surveys in the various communities they represented.

Finally, in Dctober 1967, at a conference on Indian and Metis "communications", events took place that lead directly to the formation of the manitoba Metis Federation. This conference was similar to the 
Annual Indian and Metis Conferences in that there was a large majority of Indian delegates. Inevitably the discussions gravitated to the Indian Act, band councils and reserves.

One of the topics that came up for discussion was the reorganization of the Manitoba Indian Brotherhood which had been in existence in one form or another since the early thirties. This led to the question of the status of the Metis in the organization, and whether they would be invited to join. However, the metis delegates, who felt that their special interests would probably continue to be ignored in such an organization, met separately to discuss the feasibility of forming their own organization.

Due to the unexpected turn of events, the conference was extended an extra day to discuss and vote on the matter. The official result was the decision to form two separate organizations, the Manitoba Indian Brotherhood, and the organization, as yet unnamed, to represent the Metis. A committee of two was chosen to look into the formation of a provincial Metis association. A statement was issued to the effect that it was hoped that by the time of the 14 th Annual Indian and metis Conference (tentatively scheduled for March 1968) it would be possible to announce a formal organization.

Three months later, in December 1957, the Metis who were at the conference assembled again in Winnipeg and formalized their association under the title of the Manitoba Metis Federation. A charter was obtained making the MMF a legally constituted non-profit organization under the Companies Act of the Province of Manitaba.

A provisional Board of Directors was elected to hold office 
until the first annual meeting of the organization, scheduled for the ennual Indian and Metis conference. The president was the Reverend Adam Cuthand, an Anglican minister and enfranchised Indian, and vicepresident was $\mathrm{Mr}$. Joe Keeper. A provisional constitution was written and circulated for study. An initial organizational grant of $\$ 5,000$ was made by the provincial government, and a secretary and three field workers were hired for a five week period.

In April 1968 the 14th Annual Manitoba Indian and Metis Conference was held, and for the first time the Indians and Metis met separately. Reverend Cuthand was now elected as the federation's first official president. A constitution was adopted and a Board of Directors elected. The federation was subdivided into six provincial regions: Norway House, The Pas, Dauphin, Interlake, Southern and Winnipeg (see Map 1). Each of these regions was headed by a regional vice-president, who also sat on the Board of Directors of the federation.

The Manitoba Metis Housing Association, mentioned earlier, now became the housing committee of the MmF. It concluded the housing survey that was started earlier, and continued its function of applying pressure on the government for a solution to the housing problems of the metis.

The next major change in the federation occured during the annual conference which was convened in January 1969, when J. Angus Spence was nominated the new president of the federation. There has been a steady increase in the activities of the federation since that time, and recently the organization has undergore a complete restructuring, including a revision of the six regional districts (see map 2) and a 
rewriting of the constitution. 1

\section{Organization of the MMF}

1. Membership According to the constitution of the MMF, any unregistered person of Indian descent who is of the age of 18 years or over can become a voting member of the federation. A non-Indian who is married to a person of Indian descent and is over 18 years of age is also eligible. Honorary memberships are sometimes recommended by the Board of Directors, subject to the approval of the Ceneral Assembly. In addition, any non-Metis person who is interested may become an associate member of the MMiF, but he does not have the right to vote. Honorary members do have a vote, but there is a provision in the constitution that there shall not be more than two honorary memberships given in a year, with a maximum of 10 at any one period of time. As can be seen, the federation represents a wide range of individuals, and can even include persons of non-metis descent in its membership.

2. Locals The MMF represents a federation of several organizations at the community level known as "locals". While many of these have formed originally as representatives of the mmF this is not always the case. Several of them have existed for years before the formation of the MmF in the form of a local housing organization or an expressive

1

This section is based on MMF promotional literature, personal interviews, and the following newspaper articlos: Winnipeg free press, 0ctober 13, 16, 17, 1967; Winnipeg Tribune, October 13, 16, 17, 1967, and April 5, 1967. 
organization such as the Union Nationale Metisse. The constitution is so structured as to allow any metis organizations which are willing to accept the constitution of the MiF to become part of the federation without sacrificing any of their local identity. An association wishing to affiliate simply has to forward a resolution to that effect passed by that organization and signed by its president and secretary. An example can be seen in the St. Laurent local which was originally a branch of the Union Nationale Metisse, an expressive organization with headquarters in 5t. Boniface. This organization, whose aims are primarily cultural and social, was organized in 1887. When the $5 t$. Laurent local became part of the MMF, it did so without sacrificing any of its old ties with its parent organization, and still uses the name Union Nationale Metisse in all its dealing, such as signing checks.

There have also been some preliminary negotiations for the main office of the Union Nationale Metisse to become the St. Eoniface local of the federation. The federation welcomes these organizations because it gives them a ready-made representation in a metis community.

In addition to organizations joining to become locals of the MMF, it is not unknown for locals to break away from the federation. Recently several locals from communities around The pas have left the MMF and formed their own non-status native organization.

In order to be eligible for membership, the local must consist of at least nine members, and no more than one local shall be established in any community. It is usually named after the community in which it is located, for example the Grand Rapids local, the fig Eddy 
local, and so on.

The locals have three officers who are elected annually. These are the chairman, vice-chairman, and secretary-treasurer. This is where a lot of the real power of the federation lies. The mmp is an autonomous organization, and a great deal of power is delegated to the locals. Some of the activities they are responsible for are: organizing the Metis of their community, promoting the objectives of the MMF, assisting the regional committees in getting information and statistics for the MMF, working and cooperating with the regional office in the social and economic development of their communities, and acting as a local self-governing body consistent with the laws of Manitoba in areas where there is no form of self-government. Local committees are expected to meet once a month or more often if required.

3. Regions the next level of administration in the federation is represented by the regions, of which there are six in Manitoba. Currently the six regions are the Thompson Region, the The fas Region, the Dauphin Region, the Interlake Region, the Southwest Region, and the Southeast Region. These regional boundaries are established by the executive committee with consideration of political, municipal, or school bounderies and with the social and economic interests of the members. These boundaries can be shifted if it is deemed necessary: the ones currently in use represent the second version in the history of the organization (see maps 1 and 2 , pages 53 and 54 ).

Each region is represented by a vice-president who is elected every two years at a regional conference of delegates from all the 


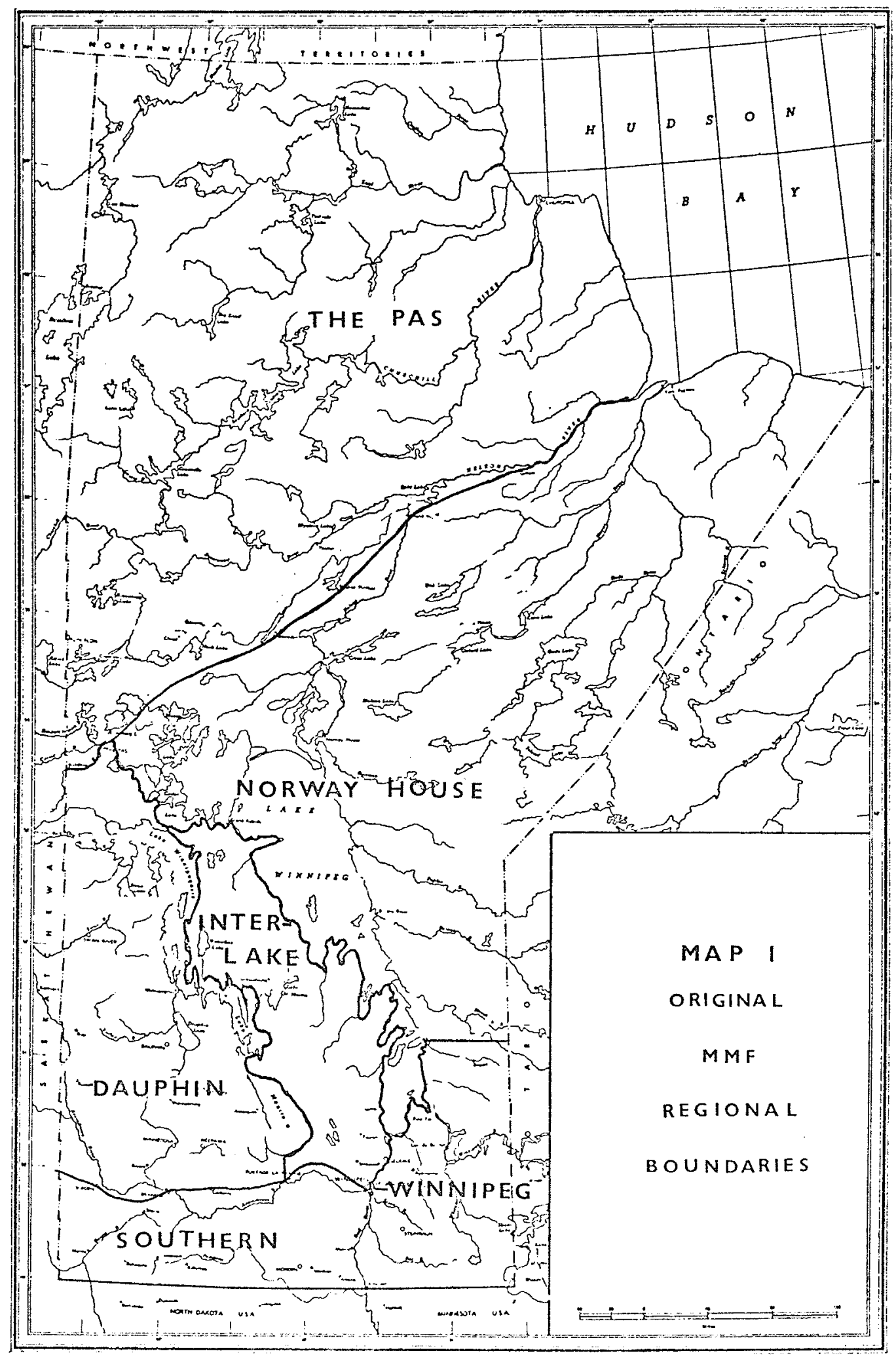




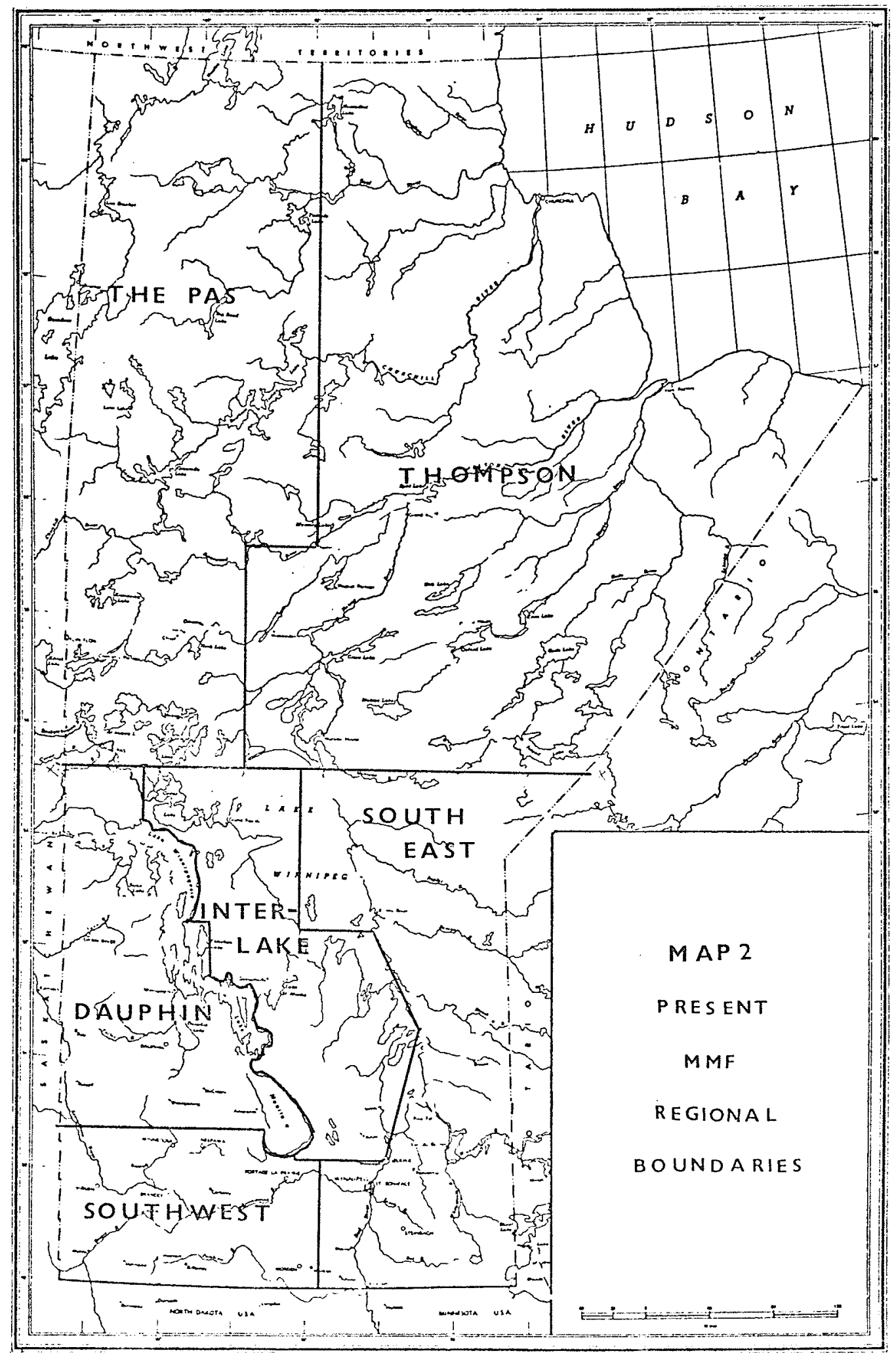


locals within the region. The term of office for the vice-presidents has been rotated so that they will not all be standing for election at the same time.

The organization of the regions is as follows: each region forms a regional committee which consists of the vice-president, the two regional members of the board of directors, the regional manager (this is a paid employee, and is therefore non-voting) and the chairmen of all the regional locals. These committees are expected to meet once a month, or on special occasions at the request of the vice-president.

The regional committees administer government grants and other funds which have been allocated to them by the MMF headquarters, are responsible for supervising the local elections, and often prepare reports and petition local and provincial governments on their own whenever they have a problem that is purely regional, or whenever they are not satisfied with the way the MMF headquarters is handling a situation.

4. MmF Head Office The executive committee, responsible for the management of the business and affairs of the federation, is made up of the president, the regional vice-presidents, and the executive director of the federation (non-voting). This body administers and manages the funds and property of the MmF, and is responsible for appointing an auditor for the federation. In addition, it has the final say on the eligibility of any person to join the mmp, or the affiliation of any organization. The committee determines the fees for regular and affiliated memberships. 
A sub-committee of the executive committee is responsible for hiring personnel for the provincial or regional offices, and acts as a final board of appeal in case an employee has been fired or claims serious maltreatment.

The executive committee is also the final authority on the legality of the MMF regional and provincial elections, and will settle any dispute relating to an election.

The next level of administration is the board of directors. The board of directors consists of the president, the vice-presidents from the six regions, and twelve members, two from each region, who are elected at the MMF's annual conference. These two members also sit on the regional committee meetings. The twelve members of the board are elected for a two-year period.

The board meets a minimum of twice a year, and on special occasions at the request of the executive committee. The board of directors is the governing body of the MmF between the annual conferences, and has the full authority to issue policy statements in the name of the MMF as long as these do not conflict with the decisions reached at the annual conferences. The board also acts in an advisory role to the president.

As chief executive of the federation, the president is a member of all committees, and presides at all meetings of the corporation and board. Although in theory the roles of the president and the vicepresidents are fairly clearly defined, in reality the positions represent a fairly delicate balance of power, and the amount of power a particular president is able to wield depends to a great degree on his 


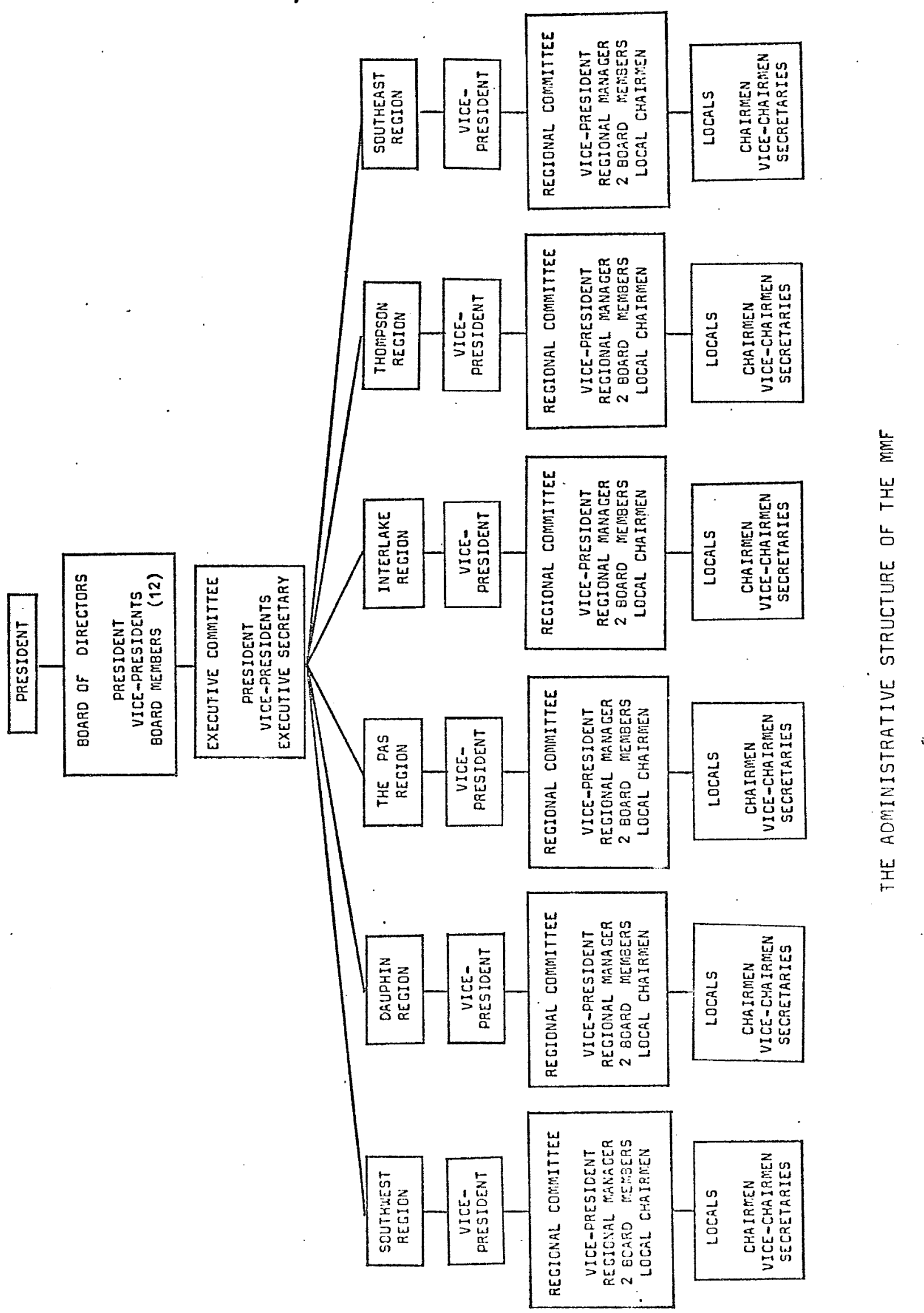


personal characteristics. There is the question not only of how much he is able to control, but how much he wants to control. There is a feeling throughout the federation that the president should not wield an inordinate amount of power.

The positions mentioned so far represent the elected officials of the federation. There are also several paid employees, such as fieldworkers, regional managers, and the executive-director of the federation. Of these, the executive-director is the most influential. He is responsible for the administrative efficiency of the MmF, and handles all funds. For example, he is in charge of the administration of scholarships which the federation has awarded to Metis students attending high school or university. He is responsible for the collection and distribution of minutes for the meetings of the board of directors and the annual conferences. He sits on all board and council meetings, but since he is a paid employee, he is a non-voting member .

\section{The operation of the me}

The constitution of the MMF, as ratified by the 3rd general conference at The Pas, Manitoba, November 1971, states the aims of the organization to be as follows:

a) To unite the Matis people throughout the province of Manitoba

b) To promote the economic education and social development of the metis people 
c) To promote the identity and recognition of the Metis people

d) To promote the participation of the Metis people in all areas of the community, in municipal and provincial organizations

e) To ensure that all metis people are aware of, and are provided with, their legal, social and political rights

f) To promote the history and culture of the Metis people and to propagate the role of Louis Riel and the Metis people in the history and development of Western Canada

These six objectives actually resolve themselves into two main areas of attack: (1) on economic development, with an effort on the part of the MMF to open new opportunities for employment for the Metis, to improve the general conditions of housing for the Metis, and so on, and on cultural development, with attempts to reinforce and rebuild the pride of being Metis.

Eidheim (1968:214) has provided a useful two-part explication of the processes which voluntary ethnic organizations use to achieve their goals -- the activization of commitments and the presentation of relevant results. He was discussing the role of voluntary organizations among the Lapps in Norway, but the analysis has an equal validity for the Metis of western Canada. "Activization of commitments" refers to the technique of pointing to the dormant principles in the moral order subscribed to by the dominant society, as well as the codified rules and principles operating in the state society, and pointing out how they are not being enforced with regard to the minority population. "Presentation of relevant results" is the technique whereby "achieve- 
ments won centrally are played out and transferred in the ... local communities in such a way that they can generate behaviour which is registered as the type of gain with which one can return to the central government and produce further achievement, which again may be transferred locally, etc." (1968:215). The federation also uses the presentation of relevant results in another way -- to attract new members to the organization. This will be made clearer in the next chapter dealing with group cohesiveness.

In order to successfully fulfill its commitments, the federation has two tasks -- it must unite the Metis, and it must materially advance their cause. Both of these are inextricably interrelated; to be able to gain concessions from the government the MMF must be able to demonstrate that it has a fair amount of metis support, and that it is capable of achieving useful advances in areas the government is interested in supporting. In order to attract members to the organization, it must be able to demonstrate its ability in gaining useful concessions from the government.

The federation achieves this by acting mainly as an agent for seeking action from government problem-solving units such as Manpower or DREE (Department of Regional Economic Expansion). The current attitude in many of these government departments is quite conducive to to cooperation with voluntary native organizations, since many civil servants as well as elected officials have begun to accept the criticism of native spokesmen that failure of government programs is usually due to civil servants and administrators who don't understand the native's Iife-styles. 
The existence of organizations such as the MMF and the MIE give government officials an opportunity to turn over the responsibility for the implementation of programs to the natives themselves. It would not be stretching the facts too far to refer to these organizations as quasi-government corporations, since not only are they involved in helping to implement government policies, but also in determining these policies as well (Kerri 1970:32).

As mentioned earlier, one of the main strategies used by voluntary organizations in gaining concessions is the activization of commitments. In their negotiations with the provincial government, the Manitoba Housing and Renewal Corporation, the Department of Regional Economic Expansion, and so on, the members of the MmF take pains to point out the injustice of the position of the Metis in Manitoba; the historical facts regarding their being swindled out of their land grants, the poor economic condition of most of the smaller northern communities, the fact that for many years the metis could not even get as good schooling as was available to Indians on reserves, and the overcrowded conditions of their houses. And the tactic has been fairly successful, because while they have no more legal standing than any other ethnic group, they have managed to acquire a great deal of governmental aid in bettering their economic position.

In turn, it is the ability of the MmF to demonstrate these gains on the local level (the presentation of relevant results) which brings the people together to try for still more achievenents. When the federation does not make much immediate gain in a community, interest 
may drop off. This was often demonstrated during the Remote Housing Program. When locals were first presented with the possibility of having houses built in their community, interest was high. Housing surveys were conducted with enthusiasm by the local members and sent in to the main office. But since only a few communities were scheduled to receive houses, there was inevitable disappointment in many communities. In one or two instanies the locals ceased operation, although this was rare. But one such community, which was close to an area which did receiva housing, was able to reformulate a year later. According to the chairman of the local, the example of what could be achieved by having a strong local encouraged them to give it another chance. Perhaps the best way of demonstrating the success of these tactics is to describe in some detail a few of the varied operations the MmF has been able to institute in recent years. These projects can be broken down into three levels; those instituted by the provincial level of the federation's administration, those instituted on the regional level, and those on the local level.

1. Provincial Level One of the most ambitious projects the federation entered into on this level was the Remote Housing Evaluation Project, made with the cooperation of the Central Mortgage and Housing Corporation (CMHC) and the Manitoba Housing and Renewal Corporation (MHRC). Even before the inception of the MmF the Metis of Manitoba had been petitioning the provincial government to help improve housing in the north. With the introduction of housing programs on the reserves, and the repeatod contention of Metis leaders that housing was of even 
more importance to the well-being of the Metis than education, some notice of this problem was finally taken in government circles. In early 1968, the manitoba government began considering a housing program for metis in remote areas. The mmF stressed that they wanted a project that not only would provide houses, but would provide jobtraining, employment, and community development as well.

An agreement was signed in 1968 between MHRC and CMHC for the financing of 100 homes over a two-year period. The MMF acted as an agent for MHRC in that they were asked to select ten communities in Manitoba that needed housing most, and to rank them in terms of priority. On the local level, the mmp formed housing associations in these communities and selected the ten families who would receive the houses. Over a two-year period (1969-1970) ten houses were built in each of the ten communities.

It was at this point of the program that the leaders of the MmF felt their control of the project slipping away from them. It was felt that the federation should involve itself more before all contact with the project was lost. This was reinforced by the mostly negative feedback they were getting from the recipients of the housing. MHRC was ignoring the recipients' wishes as to the location of the houses, and there were complaints about the quality of the workmanship as well. The leaders of the mmF decided that before expanding the present housing project, an evaluation of the entire program was necessary, and that the MmF was the most likely agent for carrying out this evaluation.

Thus, applying for and receiving a grant from CriHC, they launched 
their evaluation study of the Remote Housing Program in the summer of 1971. Resource people were hired to plan the investigation and write the report, and questionnaires were administered to all recipients of the houses as well as a selected control group. The report, which was completed in september 1971, has had a significant impact on this and other remote housing projects planned for northern Manitoba, with regard to such aspects as the criteria for choosing the recipients, the construction of the houses, the repayment scheme, and the availability of alternate floor plans.

This example is useful because it demonstrates a common tendency of many of the governmental programs aimed at alleviating economic and social disparities. These programs often degenerate from the original aim of providing services for the underprivileged sector of the population into a bureaucratic routine which merely constricts the poor and the options open to them even further than before. There is a great deal of justification in many of the Metis' complaints that the civil servants in charge of aid programs seem more interested in pushing through programs that they feel to be "good" for the people rather than listening to any of the demands that these people might make. Often the so-called consultations between native leaders and governmental departments become little more than token exercises, and more than once native leaders have felt control of programs ostensibly for their benefit slipping away from them. In the case of the Remote Housing Program, the mif had to fight hard to regain control of the project, but the fact that they were at least partially successful bodes well for their succoss in dealing with other governmental programs in the 
future.

It is also an unfortunate fact that many government officials tend to look upon native organizations as a convenient vehicle for stifling outspoken native leaders as well as white critics. Ey granting large amounts of money to these organizations, the government is able to divest itself of a great deal of responsibility. If the organization which has Ieceived the grant is able to accomplish something, well and good - - the government can take credit for having the farsightedness of allowing the people themselves self-expression. If the organization is unable to do any good, the government can then point to the example to underline the uselessness of allowing natives any say in governmental policies that concern them.

However, working with these programs is about the only realistic option open to the metis at this time. Here are some of the programs the MMF has tried to work with in the past.

The Department of Regional Economic Expansion (DREE) has as its primary goal the reduction of regional economic disparities in Canada, and as such, it has several programs which are of interest to Indians and Metis. In the prairie provinces, almost all of DREE's activities that apply in the mid-northern areas are affecting native people, since most of the population in these slow-growth areas are of native origin. One of their programs, designed to help Indians and metis, is the Agriculture and Rural Development Act (ARDA). This program covers such projects as Natural Resource Development (agricultural projects, recreation and tourism, and fisheries projects); Humon Resource Devel- 
opment (occupational training, adult education, counseling): and Development of the Arts and Crafts.

Other projects undertaken by the department include the Prairie Farm Rehabilitation Administration (PFRA) which is devoted to the expansion of pasture land; Canada Newstart, an action-research program to study the social implications of new industries and technologies in slow growth areas, and the Fund for Rural Econumic Development (FRED) which is currently conducting a ten-year program in the Interlake region of Manitoba for the development of natural and human resources. Unfortunately, many of these projects seem more impressive on paper than they do when finally put into effect. As an example, we can look at the latest ARDA agreement, signed June 9, 1971. A joint ARDA committee of representatives of both Canada and Manitoba was formed with respect to the programs and projects that this program would cover, and representatives from both the MMF and MIB were invited to sit in on the drafting of these programs. However, as late as January, 1973, there were many complaints from native leaders that grants to expand farming, fishing, and business enterprises were still being held up.

2. Reaional Level One of the most important programs on the regional level used to be the sending out of fieldworkers who were helping the federation to get organized on the commuity level (this program has for the most part been abandoned due to lack of funds, although some regions still have active workers). The fieldworker was expected to organize and strengthen the locals by advising them and providing 
information for them, but he was not to make any of their decisions for them. He had to understand and be able to explain the constitution of the federation, know the consultants in Health and Social Services and other government agencies such as manpower, and have a working knowledge of Alcoholics Anonymous programs. He had to know and apply flexible parliamentary procedure to the meetings of the locals. His over-all role was one of getting the locals started off so that he could eventually withdrau entirely, and let the incipient organization carry on by itself. The fieldworker was expected to become part of the communities that he was working in. In this way he was very much like a community development officer, attempting to act as a catalyst to social action, rather than as an active agent in pursuing results. The actions I have portrayed are those of the ideal fieldworker and, of course, things did not always work out as smoothly as described above. There were constant complaints that, on the one hand, either the fieldworkers did not do enough for the locals, were never at meetings, and did not participate, or on the other hand that they were too domineering, taking over the meetings and imposing their will on the locals. However, despite all these difficulties, the federation has been able to achieve a strong network of locals throughout the province, and the fieldworkers must take a great deal of credit for this.

3. Local Level In addition to the work done on the provinciel and regional levels, some of the more powerful locals have initiated some 
impressive projects on their own. One such project was the Amisk Construction Company, which was involved in securing bush-clearing contracts in northern Manitoba. This was a cooperative formed by the Wabowden Local to take on work contracts available to Indians and metis. It was a non-profit organization; the profit from the work contracts was given to the workers after administration and other pertinent costs were allowed for.

This project ran into government opposition in 1970 when the Minister of Transport objected to the fact that the chief of the Cross Lake Indian Band approached the general manager of Amisk to handle a bush-clearing contract for Manitoba Hydro that had originally been awarded to the band.

Another example of a project conceived and executed on the local level is the cooperative woodworking plant in St. Laurent, Manitoba, which was officially opened in March, 1971. This factory produces wooden ladders, church furniture and other finished products, and is expected to eventually branch out into full-time furniture production. This factory got under way when the federation's St. Laurent local came to the conclusion that their community needed a stronger economic base if it were to survive for more than a few years. It was necessary to drive $60 \mathrm{miles}$ to Winnipeg to find work, and more and more people were leaving the community.

The local began the project by buying the town's old elementary schoolhouse and some adjoining land. Covernment assistance came in the form of help from the departments of agriculture and industry on the provincial level, and from DREE on the federal level. The in tial 
woodworking equipment was purchased by DREE through its FRED program, which provided financial assistance to train the employees as well. The provincial industry department staff provided marketing and organizing experience and the Manitoba Development Corporation guaranteed a bank loan which the St. Laurent local obtained.

\section{Contacts With Other Native Oroanizations}

The federation maintains contact with many native organizations across Canada, but limits most of its cooperation with the non-status Indian or Metis organizations. While this is mostly due to the fact that these groups share similar problems, and therefore should logically cooperate with each other, this feeling can also be seen as the reflection of some of the bitterness which exists between registered and non-registered Indians.

Nowhere is this mare obvious than in the strained relationships which exist between the MMF and the MIB. Although it is rarely admitted to publicly, there is a lot of feeling of resentment for the MIB by the various members of the federation. This feeling dates from the time when they were a part of the Indian and Metis conferences and felt that their. problems were being ignored by the Indians, and is exacerbated by the feelings of frustration at seeing the many special programs the federal government has for Indians (such es housing) for which they are ineligible. The leaders of the mm are fond of pointing out that they "have the same problems of the Indians but don't share the same advantages." 
An example of the mistrust which exists between the two organizations occured when I was working on the Remote Housing Evaluation Project. A representative of the MIP engaged in a housing survey came to the federation seeking information about the MmF's housing survey. The director of the housing project gave very little information and afterwards told me that they wouldn't give the mIB any information until they had some evidence of getting a little information about the Indians' project in return. To my knowledge, neither side has volunteered any information since that date.

There is a better spirit of cooperation between the federation and other Metis organizations such as the Metis Nation of Saskatchewan or the Alberta Metis Association. Requests for information about the housing projects made by these organizations were readily answered, and in fact the federation's program was bas $d$ on a similar one in saskatchevan.

On the national level, the metis and non-treaty Indians of Canada are now being represented by the Native Council of Canada. This organization was formed in December 1970 when the executives of the provincial Metis and non-status Indian associations of British Columbia, Alberta, Saskatchewan and Manitoba started a series of meetings to discuss the possibilities of organizing a national metis and non-status Indian organization to establish a direct line of communication with the federal government. In February 1971 a constitution was drawn up and the organization now has offices in ottawa and is already making some progress in getting recognition of their special needs from the federal government. 


\section{Representativeness of the Organization}

Just how many Metis does the Manitoba Metis Federation speak for? At the time I was working for the Remote Housing Evaluation Project (summer, 1971) the federation had no really clear idea of how many members it had, but it did have a fairly extensive representation

among the various Metis communities of Manitoba, with approximately 54 locals. In a map produced by the Community Welfare Planning Council in 1968 which showed all of the Indian and metis communities in Manitaba, 102 metis communities were depicted. The number of locals has increased rapidly in the last few years. At the general conference of March, 1972, delegates from 72 Metis communities were represented. And in a recent telecast (January, 1973) the president of the MmF, Angus Spence, mentioned that the federation was currently working in 98 communities.

\section{Representativeness of the Leaders}

Dne often hears complaints from certain members of the federation (and even from members of the MIB) that the MMF is not a true metis organization becauce its founding members (Rev. Adam Cuthand, Tom Eagle, and Joe Keeper) were all enfranchised Indians and not "born Metis". The controversy hinges on the ambivalent attitude that is often held by Indians and retis with regard to legal status. Although the mim is the only organization that an enfranchised. Indian can belong to, those who wish to criticizo the Min have a ready-made club, saying that it is being "controlled by Indians". 
This criticism has lost some of its bite since the president, Angus Spence, was elected; he never has been a treaty Indian. However, one occasionally hears criticism of another sort from metis leaders of the more northern regions. Mr. Spence comes from the Dauphin region (he is a successful rancher there) and some people offer the criticism that he "can't represent the North". Since each region has its own vice-president (the federation being set up this way to give equal representation to all regions of Manitoba) these criticisms can probably be regarded as electioneering statements made by those with an eye on the presidency.

It would be interesting to discover just how representative the leaders of the federation are on all levels -- local, regional, and provincial. However, this would require a survey taken across manitoba, asking members of the communities who they regarded as their leaders. It is probable that the people would turn to their local chairman or vice-president rather than to the president. There is, as has been mentioned, the intense feeling of local autonomy, and the feeling that the president "can't tell us what to do".

A survey is also needed to determine the frequency of participation that the local people give to their organization. In one case, Grand Rapids, the most frequent method of participation in the affairs of the local was through the weekly bingo games. Having been to many different locals and having sat in on many meetings, it became obvious that there are strong locals as well as those that do not have too much local participation. This situation is also felt in the main office of the MMF, where certain locals, perhaps because of strong leadership 
(perhaps the chairman is also the vice-president of the region), strong participation of the rank and file, or a cambination of both, make themselves felt much more than others. Now that we have some insight into how the Mimf operates, how its leaders are chosen, the aims and objectives of the organization, the means that are used to gain concessions from the government, and the number of people the organization represents, we are able to consider the effects that the federation may have on the ethnicity of the metis of Manitoba. This is the subject of the final chapter. 
CHAPTER 5

VOLUNTARY ORCANIZATIONS AND ETHNICITY

For the most part, contemporary ethnic organization is political in nature. Since it has long been conceded that self-determination is the standard of justice in international politics, it is not surprising that there is an increasing tendency for smaller groups to demand the same standards be applied to them. In Britain, for example, there is a renewed interest in Scottish and Welsh self-identification, as the old concept of British nationalism is no longer capable of suppressing ethnic consciousness. There is a similar situation in Canada, where the concept of Canacian rationalism is unable to stifle the desire for self-determination within Quebec.

The rallying cries behind this seemingly universal tendency towards self-determination are usually based on the inferior economic, political, or social position the ethnic group occupies with respect to the majority of the society. One of the main avenues open to these groups is the formation of voluntary organizations, a basic tactic in situations where special problems cannot be adequately handled by the constituted public apparatus. These organizations generally are concerned with wresting control from governments over money to be used for ethnic economic self-help, or for educational or social functions. The prolifaration of these organizations (which Borth refers to as subpolitical advancement associations 1969:34) is a world-wide phenomenon, 
and represents the special interests of such disparate groups as metis, Lapps, Chicanos, Blacks, and Indians.

But it is naive to expect that reconciliation and social harmony can be achieved merely by satisfying the specific greivances of these minorities. As I intend to point out later in this chapter, merely the process of fighting for and achieving concessions generates an increase in group consciousness. Black Americans, for example, have greatly improved their economic and political positions in the last decade or so, and their group identity has grown stronger in the process. The same could be said for the French Canadians, the Metis of western Canada, or several other ethnic groups.

\section{Group Cohesiveness}

In order to analyze the effects of voluntary organizations on the feelings of ethnicity of members of ethnic groups, some use could be made of the experimental literature that exists with regard to the cohesiveness of groups (Gutte ag 1970). For our purposes, cohesiveness can best be defined as "those forces which act to keep a person in the group and prevent hin from leaving" (Collins and Raven 1969:120). There is a large amount of literature on the concept of cohesiveness (a review article by Lott and Lott, 1965, deals with over 290 articles published between 1950 and 1952). Not all of these studies are germane to the problem at hand, but there are several generalizations that have been postulated which are adaptable to the situation of ethnicity and Sthnic group persistonce. 
In the studies that concentrated on the effects of frustration and threat on groups, it was shown that attraction among individuals was increased with the realization that: (a) there is a common threat sterning from an external source, and (b) there exists the possibility that cooperative behaviour may reduce or eliminate the threat (Lott and Lott 1965:266). Further, group cohesiveness is enhanced when people in low status groups cannot, as individuals, achieve mobility (Guttentag 1970:111). Conversely, group cohesiveness suffers if individuals are able to achieve mobility as a result of individual effort, or when instrumental groups are continually confronted with failure (but not when cohesiveness is based on mutual acceptance) (Guttentag 1970:111).

These aspects of group cohesiveness have particular relevance to the contemporary, predominantly political organization of ethnic groups today. It seems likely that voluntary organizations can be strengthened, as well as strengthening group identity by demonstrating some success at achieving concessions for the group. In this way they would be demonstrating the possibility that cooperative behaviour may eliminate or reduce the outside threat. A great many ethnic groups, including the metis, display an extremely low rate of individual mobility (with the exception of those who were successful at "crossing the ethnic boundary") and any example of group success should make clear the assets to be gained by claiming membership in the group. Conversely, If the voluntary organization is unable to demonstrate much success then it would be unlikely to have much effect on group cohesiveness. An example of the striking effects that voluntary orgenizations 
can have on group consciousness can be seen in the effects generated among the Blacks of North America by such organizations as SNCC, NAACP, the Black Panthers, and the Black Muslims. The process of fighting for and winning concessions, which started in the fifties with sit-ins and similar strategies has in itself generated a renewed consciousness of kind which continues to grow with each victory. The pride and selfconfidence produced by the victories won soon resulted in the attitudes that assimilation and integration were the ideals of the "Uncle Tom" and the newer political ideals of separateness, identity, and autonomy became the order of the day.

This is no place for a full analysis of Black thought and ideology, but an example of Stokely Carmichael's concept of "Black Power" should demonstrate some of the aspects of Black ideology developed by SNCC once the movement for self-advancement was well under way. Attacking the concepts of integration which was so often the ideal of meny individuels in black and white society at the time (midasixties), Carmichael felt it was "based on the conception that there was nothing of value in the Negro community ... so the thing to do was to siphon off the 'acceptable' Negroes into the surrounding middie-class white community." Such a concept was aimed "not to develop the black community as a functional and honorable segment of the total society, with its own cultural identity, life patterns and institutions, but to abolish it -a the final solution to the Negro problem" (1966:645). of course the new ideology that has sprung up anong the 8lacks of North America within tho last few decades ("Black is beautiful"; the pride in Negritude, etc.) is not the product of any one group or 
organization, but it represents the continuing political mobilization of ethnic groups, the conception that their problems stem from an outside source, and the recognition of the necessity of cooperation for the reduction or the elimination of the threat.

This example does not have complete relevance to the Metis situation since the case of the Blacks is complicated by the much larger population involved and it represents the result of a great many more organizations and factions than is the case for the metis in Manitoba or even Canada. An example that may be of more relevance can be seen in the example described by Eidheim (1968) regarding the Lappish movement and the efforts of several voluntary organizations to promote their special interests in Scandinavian society.

The position of the Lapps in relation to Scandinavian society is strikingly similar to the position of Metis in Canadian society. Like the Metis, they live in peripheral areas, are divided by cultural differences, particularly as between sattled and nomad (note the similarity here to the cultural gulf between the "Red River" Metis and the northern metis) and they lack a traditional organizational apparatus by which they could promote common interests within modern European society. But despite this lack of unity and organization, their marginel position has protected their ethnic identity.

There is an assimilation process at work in the Lappish/ Scandinavian plural society similar to that in Canada. For a long time, individuals with Lappish identity wishing to pursue careers in the dominant society had to adopt a Scandinavian or Western European way of life. Lappishness has a stigma of inferiority sanctioned by 
ridicule, insults, and avoidance (see also Eidheim 1969). Put a Lapp shedding his identity was then involved in a similar cost from a Lappish system of sanctions when he wished to change his identity. This process is still in effect today, although in a somewhat reduced force thanks to the efforts of the Lapps and their voluntary organizations. These organizations first made their appearance shortly after World War II. A. small group of Norwegian Lapps, concerned with preserving their cultural identity, formed a group of three voluntary organizations, representing a wide range of interests for the Lappish population, such as a desire for exclusive rights to natural resources, and Lappish-oriented school-systems and curricula.

Later the representatives of these voluntary organizations created a Lappish inter-Nordic organization which gave them new strength, allowing them to make direct joint applications to the interparliamentary Nordic council, playing the states off against each other to gain further political concessions.

Thus the innovation of these voluntary organizations has been similar to the process by which the MMF is now functioning: first the institutions in which power is invested are identified, then the system is broached by means of a voluntary organization which feeds information and dernands into the system (Eidhein 1968:214).

At first these organizations had little effect; even when some concessions were gained there was much local resistance, even on the part of some Lapps as well as of local whites. However, they soon began to achieve their main goal, that of focussing attontion on the Lepps as a separate group or category with special claims to rights in 
the plural society.

A genuine alternative was now open to Lappish people - - the status of Lapp had acquired a content for them. The rights which have been gained are founded on a consciousness of the Lapps as a cultural entity. The concrete manifestation of this is that more and more young Lapps are able to take up career coles while maintaining their cultural identity.

Eidheim has provided a useful format for analyzing the process by which voluntary ethnic organizations achieve their goals: the activization of commitments and the presentation of relevant results. These have already been discussed in Chapter 4 , but they have some relevance here as well, concerning the concepts of group cohesiveness. For convenience's sake, I will briefly repeat the definitions. "Activization of commitments" refers to the technique of pointing to the dormant principles in the moral order subscribed to by the dominant society, as well as the codified rules and principles operating in the state society, and pointing out how they are not being enforced with regard to the minority population. "Fresentation of relevant results" is the technique whereby "achievements won centrally are played out and transferred in the Lappish local communities in such a way that they can generate behaviour which is registered as the type of gain with which one can return to the central government and produce further achievements, which again may be transferred locally, etc." (Eidheim $1968: 215)$

Some of the techniques that Eidheim demonstrates can be explained through the concept of group cohesiveness. The presentation of rele- 
vant results as a tactic to gain new following and strengthen the movement has its roots in the observation that (1) cohesiveness is increased when individuals see the possibility of united action eliminating on outside threat, and (2) when instrumental groups are successful in their efforts.

The potential for the reactivization of Lapp identity (which successfully breached the gap between nomad and settled Lapp) was further strengthened by another generalization of group cohesiveness; that cohesiveness increases when people in low status groups cannot, as individuals, achieve mobility. The young Lapps that Eidheim mentioned who are now able to pursue careers as Lapps, were not able to do so until effort was made on their behalf by these valuntary organizations.

As for the realization that their troubles stem from an outside source, it was not too difficult for the individuals ploting the course of these voluntary organizations to convince the Lapps that their troubles lay in the dominant Scandinavian society, since it was this society which held all the fower and economic controls while the Lapps were relatively powerless.

This example of Lappish voluntary organizations implies that some prerequisites are necessary before a similar situation can repeat itself: (1) there must be a stigna of inferiority, or at least outsidedness accorded the minority group: (2) there must be the constitutional freedom to establish separate voluntary organizations; and (3) there must be a sufficiently strong overall goal to be able to unite the factions and sub-groups that are invariably part of any othmic 
group. In the case of the Lapps, the goal was to change the inability for a Lapp to take part in the society as a Lapp. A similar situation is in effect for the metis in Canada.

\section{The MMF and Metis Identification}

Barth described three choices open to members of ethnic groups attempting to participate in the dominant society: (1) they could attempt to pass and become incorporated into the dominant group; (2) they could adopt a "minority" status, participate in the larger system and limit all cultural differences to areas of non-articulation: (3) they could choose to emphasize their ethnic identity, using it to develop new positicns and patterns in the society (1969:33).

Individual metis have tried all three of these possibilities with varying degrees of success, but the third alternative really had to wait for a joint action by a large number of Metis before it could have much chance for success. This third avenue represents the strategy that is being pursued by the leaders of the Manitoba Metis Federation.

Three prerequisites were mentioned earlier which were necessary for a voluntary organization-based movement towards cohesive action on the part of ethnic groups -- stignatized status, the freedom to form legally constituted action groups, and a common goal strong enough to unite any factions or sub-groups of the ethnic group. All three of these prerequisites exist in the metis situation -- the Metis share the same stigmatized low status generally accorded the rest of Canada's 
native's population, the MMF is a legally incorporated organization and is therefore free to make formal contact with governmental departments, and, as indicated in Chapter 4, the organization has sufficient strength to attract a wide range of Metis into the organization, from "Red River" Metis to northern metis.

Cohesiveness was said to increase when group members perceive a common threat from an external source. Many metis already hold the opinion that their underprivileged position is a result of the dominant and external society's control of the power and wealth, and of its attitude towards them as a low-status group. This in itself is enough to promote a feeling of ethnicity and cohesiveness, but the mmF is able to define this threat more clearly by identifying the institutions in which power is constituted, and by demonstrating to its members methods of feeding information and demands into the system. Not only does this pinpoint the source of the Metis' problems more clearly, it performs a second action which promotes cohesiveness; demonstrating to the group members that a possibility exists for cooperative behaviour which may reduce or eliminate the threat.

When people in low status groups cannot achieve mobility as individuals, their identification with the group increases. The MmF heightens this cohesiveness by helping the Metis achieve mobility as a group. For example, metis have had trouble getting work in the mining operations at Thompson for several reasons. The trouble stemmed partly from the difficulty the individual experienced in adjusting to the idea of steady employment, the difficulties experienced in finding accommodation and relocating in Thompson after living in the smaller 
northern communities, and finally, the company's reluctance to hire any more Metis because of the high turnover they had experienced with individuals who could not make the necessary adjustments. The MmF has now instituted a program (financed by the Provincial government) which helps Metis find jobs and relocate in Thompson by providing homes for their families and providing counseling services aimed at helping them adjust to their new way of life. Here is a concrete example for identifying as a Metis -- it helps the individual make a successful adaptation.

The housing program the MMF instituted also helped to raise the standard of living for the Metis. The MMF also took part in the negotiations for the special ARDA program mentioned in Chapter 4, which provides grants to Metis people who wish to expand their farming, fishing or business enterprises. Another avenue for mobility as metis has been recently provided by the MMF with the establishment of the Manitoba Metis Development Corporation (MmOC) a non-profit organization Iegistered under the Companies Act of Manitoba, which will seek funds. from government and private sources to be owned and controlled by the MmDC. Metis will be trained to manage and operate these Mmoc projects. There is another way in which these operations contribute to Metis ethnicity - many of the jobs created by these programs foster a continued isolation from the dominant society. The ARDA grants have made it possible for several "native oriented" sources of income, such es fishing, to continue. For many metis, this negates the need for making any attempt to join the dominant society. A fish-packing plant employing 40 metis and a fishing cooperative on Lake manitoba are two 
examples of this.

Today, contending ethnic groups often become differentiated with respect to educational level and attempt to control or monopolize educational facilities for this purpose (Barth 1969:34). One of the implications of studies of the Amish and Hutterites (Hostetler 1963; Kaplan and Plant 1956; Guttentag 1970) is that control of their own educational system has been an important aspect of group survival. This situation is no longer viable in western society -- the trouble these groups have had with respect to controlling their education is indicative of that. Groups that are attempting to stress their ethnicity in western society today, such as the Metis, are faced with strongly institutionalized organizations which have taken over functions such as education. The only way for the metis to gain back some measure of control over their education besides voting in school districts and getting on school boards is to gain control over some of the money slated for education from the government. The MmF is attempting to do this with one of the educational grants it is seeking from the provincial government.

They cannot use the money to set up a separate educational system, so the money is earmarked for bursararies for Metis students. By stipulating what courses make a metis student eligible for a bursary, the federation is gaining back a certain amount of control over the educational system. For example, the bursaries in this particular grant are intended for students going to university, technical colleges, or nursing training, to assist students of poor 
Metis families get through high school, and to pay for single courses in sociology, anthropology, philosophy and psychology.

\section{Conclusions}

The activities of the MMF can be regarded in Barth's terms as those that are fostering boundary maintaining contacts. The most impressive gain they have made to date is convincing the provincial government that they exist as a special group. They have managed to get programs for themselves (Remote Housing Project, special ARDA) that no ordinary ethnic group without aboriginal rights (which is all that the Metis officially are) could have possibly received. Prior to the efforts of the MMF, the Metis were a "non-people" -- the government would not even acknowledge that they existed.

This gaining of recognition from the provincial government has now lost its innovative character, and is in the process of becoming an institutionalized political process. As long as the mmp officials are successful in their achievements on the local level, generating behaviour which is regarded both by the members of the Mmf and the government as proof of a type of gain (e.g. creating employment) they can return to the government and gain more resources.

The success of their contacts with the provincial government has encouraged the members of the mmi to try the same process with the federal government, which up to now has not been too sympathetic to their demands. They have submitted a request for a grant from the federal government to support the needs of the administration, regional 
offices, staff, and conferences. If such provincially-based requests prove to be successful, the gains made by the provincial metis and non-status Indian organizations, together with the efforts made by the Native Council of Canada, may yet help the Metis succeed in their long struggle to gain recognition from the Federal Covernment of Canada. Structurally and functionally, this new political process is in marked contrast to that manifested by the 19th Century Metis. The "New Nation" was organized around an implicit feeling of separateness from the rest of contemporary society. Rather than attempting to co-exist with outside forces, the metis stressed their political independance, recognizing neither the authority of the Hudson's Bay Company or the Council of Assiniboia (Sprenger 1972a:22). This was underlined by a need for a physical separation as well as an ideological one, and resulted in the westward trek that many metis made to $5 t$. Laurent at Duck Lake.

It was, in fact, this inability of the Metis to cope with the rapidly expanding Canadian society that proved to be the fatal flaw of the Metis vation. They attempted to remain politically independant when it was no longer feasible to do so, and after they ran out of territory, the only sanction they had to protect themselves was force, which when spent, left them practically helpless in the new situation they now found themselves. They were unable after the second rebellion to effectively regroup to protect themselves from the land scrip frauds which were perpetrated against them, and even though they had, in theory at least, equal political status in law, they were apparently 
at a loss as to how to protect their interests in the new society.

The organization of the MMF is along totally different concepts than that of the New Nation. Today, in the face of the strong institutional and organizational arrangements of the modern state, it is no longer possible for a group to remain politically independant within Canada, and the structure of Metis organization has shifted accordingly. Rather than attempting to exist apart from the rest of society the members of the MMF see their organization as a mechanism for neootiating with the central authority. Some metis express this strategy as "fighting the white man with the white man's weapons"; thus the institutionalized political process mentioned earlier -- the activization of commitments and the presentation of relevant results aimed at gaining recognition and concessions from the government. This is actually what the 19th century metis tried to do when they realized that westward expansion was inevitable, but they were unable to do it effectively.

Besides this major shift in philosophy (from remaining separate to working within the society) there are other important differences between the organization of the 19th century metis and the contemporary Metis. One of the main factors in the organization of the New Nation was that there was one main occupation followed by the Metis -- the pursuit of buffalo, and indeed the government at Duck Lake was modeled after the organization used to set up the actual buffalo hunts. Today, the Metis do not have any one single occupation that provides them with a blueprint for their political organization the way the buffalo hunt did for the New Nation. Instead, they are orgenized around a lack of 
occupation and the need for improving their social and economic position in terms of the existing social structure.

The provisional government at St. Laurent consisted of an elected president and council, and had a code of regulations covering nearly the whole life of the community (Stanley 19360:404). While the mmF retains the idea of an elected president and council closely held subject to the desires of their constituents, the scope of the MmF is much narrower than that of the government of St. Laurent, which concerned iself with such things as the collection of taxes and law enforcement.

Another factor which has an important bearing on the differences between the New Nation and the modern Metis is the differing criteria for membership each exhibits. This has been dealt with elsewhere (Chapter 3) but it remains probably the most fundamental difference in the organization of the two groups.

The factors that the Metis of today have in common with their namesakes of the 19th century are their Indian ancestry, their marginal status, and a tradition from the past. This tradition, however, is being taken over by those who, in the strictest sense, cannot be said to be descendants of the boise-brule who roamed the plains in the 19th century. What has happened, in fact, is that the boundaries which defined the rietis as an ethnic group have been drastically changed to meet changing conditions. Eut in the face of contemporary civilization, change is an ever-present fact of $I$ ife, and survival depends in part upon a group's flexibility. Whether or not the adaptations the metis have made to the $20 t h$ century are sufficient to ensure their survival remeins to be seen. 


\section{BIELIOCRAPHY}

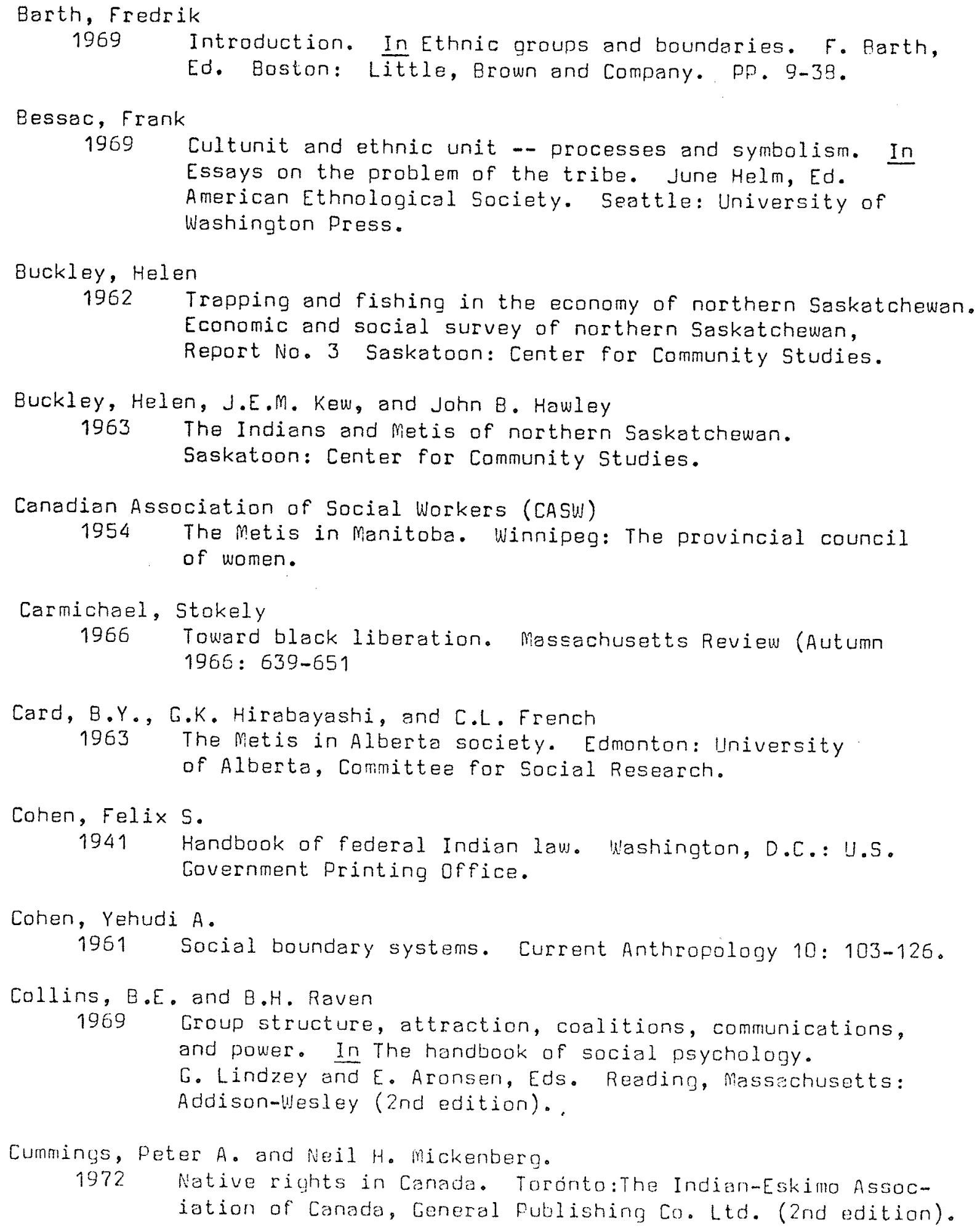




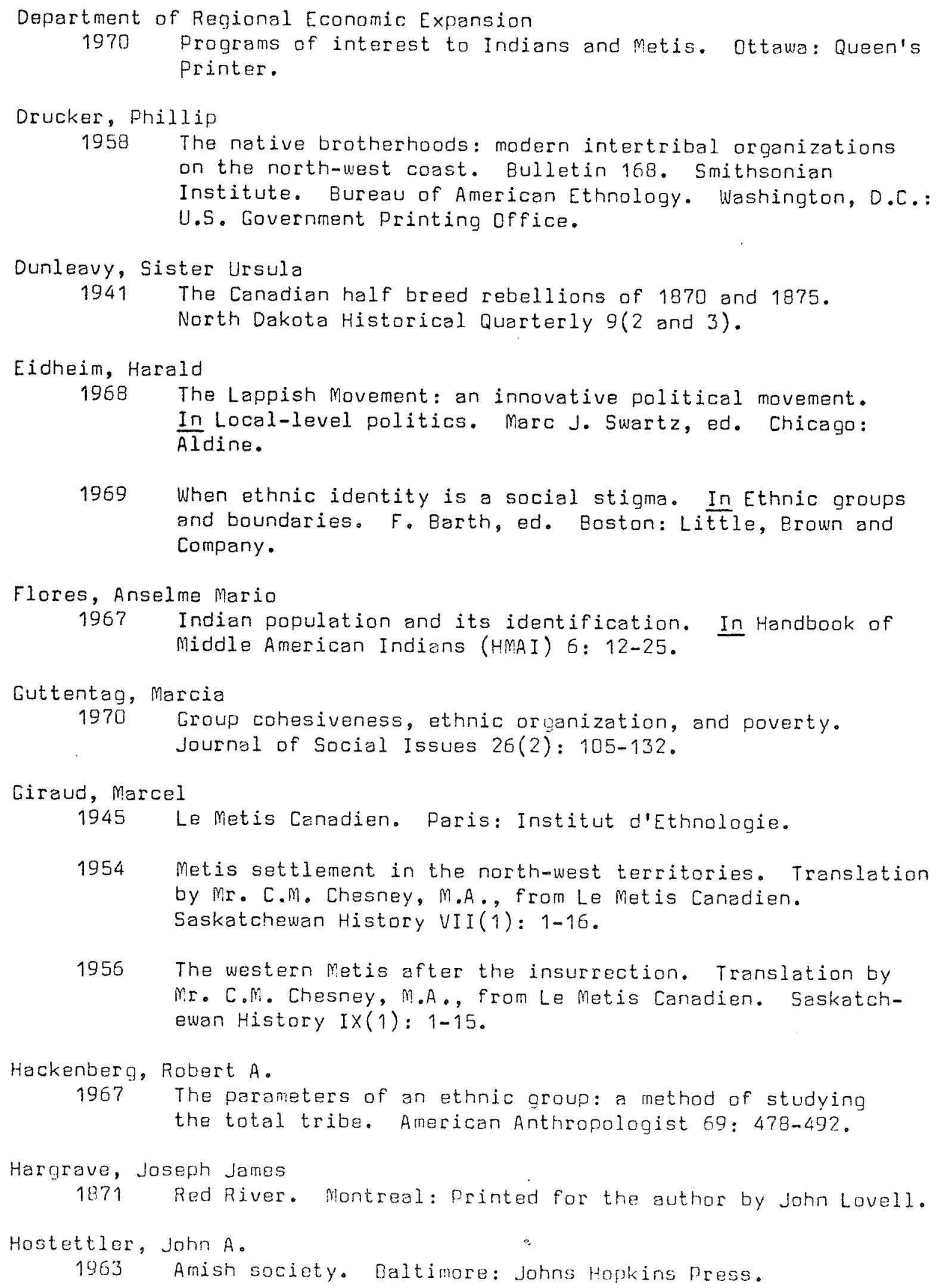

1969 When ethnic identity is a social stigma. In Ethnic groups and boundaries. F. Barth, ed. Boston: Little, Erawn and Company.

Flores, Anselme Mario

1967 Indian population and its identification. In Handbook of Middle American Indians (HMAI) 6: 12-25.

Cuttentag, Marcia

1970 Group cohesiveness, ethnic organization, and poverty. Journel of Social Issues 26(2): 105-132.

Giraud, Marcel

1945 Le Metis Canadien. Paris: Institut d'Ethnologie.

1954 Metis settlement in the north-west territories. Translation by Mr. C.M. Chesney, M.A., from Le Met is Canadien. Saskatchewan History VII(1): 1-16.

1955 The western metis after the insurrection. Translation by M. . C.M. Chesney, M.A., from Le Metis Canadien. Saskatchewan History IX(1): 1-15.

Hackenberg, Robert A.

1967 The parameters of an ethnic group: a method of studying

the total tribe. American Anthropologist 69: 478-492.

Hargrave, Jaseph James

1871 Red River. Montreal: Printed for the author by John Lovell.

Hostettler, John A.

1963 Amish society. Baltimore: Johns Hopkins Press. 


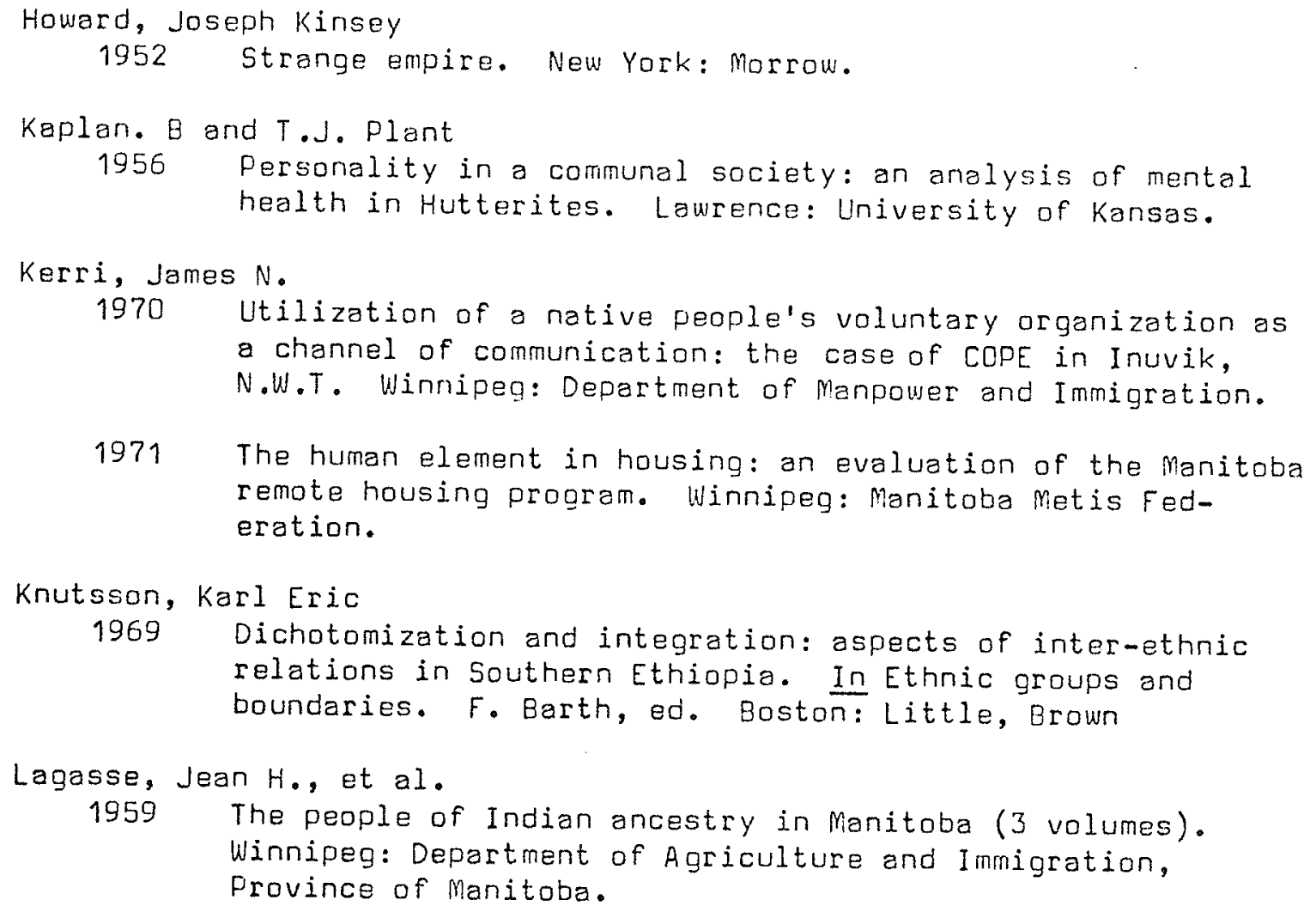


1967a Letter to the editor (a reply to R. Narol1). American Anthropologist 69: 512-513.

1967b Being Lue: uses and abuses of ethnic identification. In Essays on the problem of the tribe. June Helm, ed. American Ethnological Society. Seattle: University of Washington Press.

Morris, The Honorable Alexander, P.C.

1880 The treaties of Canada with the Indians of Manitoba and the Northwest territories, including the negotiations on which they were based, and other information relating thereto. Toronto: Belfords, Clarke and Company.

Morton, Arthur $S$.

1939a A history of the Canadian west to 1970-71. Toronto: Thomas Nelson and Sons, Limited.

1939b The New Nation, the Metis. Transactions of the Royal Society of Canada, Section 2, XXXIII, series 3, May 1939. pp. 137-145.

Morton, W.L.

1950 The Canadian Metis. The Beaver, September, 1950.

1957 Manitaba, a history. Toronto: University of Toronto Press.

Naroll, Raoul

1964 Ethnic unit classification. Current Anthropology 5(4): $283-312$.

1967a Native concepts and cross-cultural surveys. Letter to the editor. American Anthropologist 69: 511-512.

1967b Who the Lue are. In Essays on the problem of the tribe. June Helm, ed. American Ethnological Society. Seattle: University of Washington Press.

1970 The culture-bearing unit in cross-cultural surveys. In A handbook of method in cultural anthropology. R. Narcil and Ronald Cohen, eds. New York: Natural History Press.

Official Report of the Debates of the House of Commons of the Dominion of Canada

1885 July 6, 1885, pp3113. In Third session -- Fifth Parliament. Volume $X X$. Comprising the period from the sixteenth day of June to the 20th day of July, 1885.

Pritchett, John Perry

1942 The red river valley, 1811-1849: a regional study. Toronto: Ryerson Press. 
$\underset{1885}{\text { Reade, John }}$

The half breed. Transactions of the Royal Society of Canada, Section 2, 1885.

Rose, Arnold M.

1965 Sociology, the study of humen relations. New York: Alfred A. Knopf (2nd edition, revised).

Ross, Alexander

1856 The red river settlement: its rise, progress and present state; with some account of the native races and its general history to the present day. London: Smith, Elder, and Company.

Slobodin, Richard

1966 Metis of the Mackenzie District. Ottawa: Canadian Research Center for Anthropology.

Sprenger, G. Herman

1972a An analysis of selective aspects of Metis society, 1810 1870. Unpublished Master's Thesis. University of Manitoba.

1972b The Metis nation: buffalo hunting vs. agriculture in the

Red River Settlement (circa 1810-1870). The Western

Canadian Journal of Anthropology. Volume III, no. 1.

Stanley, Ceorge F.G.

1936a The birth of western Canada: a history of the Riel

rebellions. London: longmans, Green and Co. Ltd.

(Reprinted 1960. Toronto: University of Toronto Press)

1936b The half-breed rising of 1875. Canadian Hiscorical

Review, December, 1935.

1947 The metis and the conflict of cultures in western Canada.

Canadian Historical Review 28 (December): $428-433$.

1949 Cabriel Dumont's account of the North West rebellion.

Canadian Historical Review (September, 1949).

\section{Statutes of Canade}

1870 The Manitaba Act, 33 vict. Cap. 3 Sec. 31; 25-26

Valentine, V.F.

1954 Some problems of the metis of northern Saskatcheman. Canadian Journal of Ecchomics and nolitical Science 20: $89-95$

1955 The metis of northern Sasketcheman. Departinent of Natural Resources, may 1955. 
Winnipeg Free Press

1967a Friday oct. 13 Indian workshop begins saturday.

1967b Monday oct. 16 Inidian Metis program discussed.

1967c Teusday Det 17 Metis, Indians split.

1970 Friday Nov. 6 Remark angers Metis.

Winnipeg Tribune

1967a Friday Oct. 13 Indian-Metis meet to discuss communications.

19676 Monday Oct. 16 Indians, Metis may join forces,

1967c Teusday 0ct. 17 Indians, Metis vote to form two groups.

1967d Monday April 8 Federation to continue probe into claims on land; Indians launch new brotherhood.

1971 Teusday July 27 The future of the Metis: total assimilation feared. 